\title{
Salmos 32.II-36.7 y 78.25-8I.2: \\ nuevos fragmentos de la Biblia castellana romanceada del Monasterio de Santa María de la Sisla
}

\author{
Gemma Avenoza
}

Universitat de Barcelona

gavenoza@ub.edu

https://orcid.org/OOOO-OOO2-05I3-5700

Received o7/o6/2018; accepted 03/o8/2018

DOI: https://doi.org/IO.7203/MCLM.5.I257I

\section{Psalms 32.II-36.7 and 78.25-8I.2: new fragments of the medieval Castilian Bible from the Monastery of Santa María de la Sisla}

\begin{abstract}
The study of archival collections from medieval religious orders has made it possible to locate a second fragment of a medieval Spanish Bible, from the Hieronymian monastery of Santa María de la Sisla (Toledo). It is a bifolia from the book of Psalms that belonged to the same codex as the recently identified Ezekiel fragment ( $\left.=\mathrm{S}_{\mathrm{I}}\right)$. In this article the finding is reported, the liber tradens is described, specifying its meaning and value to ensure monastery rents, the fragments that it transmits are given: part of a bifolia in parchment of the s. XIII and biblical bifolia that serves as cover, focusing especially on the description of this second fragment $\left(=\mathrm{S}_{2}\right)$. Next, the relationships between $\mathrm{S}_{2}$ and Esc. I-I-3 are examined, a filiation hypothesis and, finally, a palaeographic transcription of the text are offered.
\end{abstract}

KEYWORDS

Medieval Spanish Bible translations; translations; fragments; textual criticism; codicology; Hieronymites; Santa María de la Sisla monastery

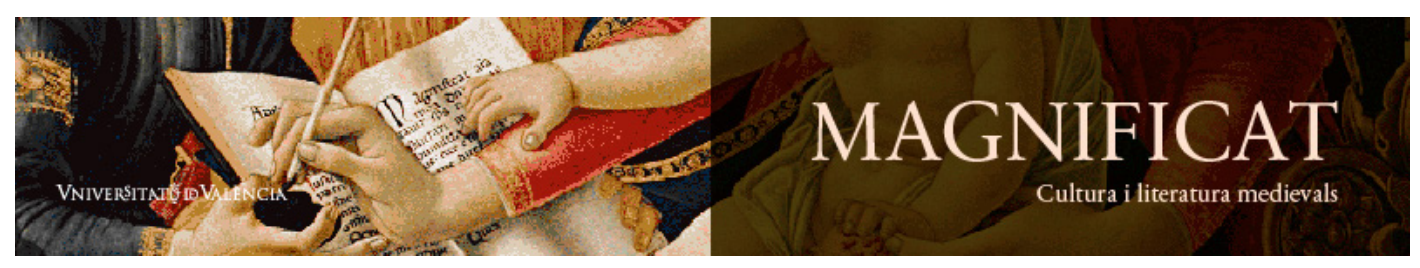

Magnificat Cultura i Literatura Medievals 5, 2018, II5-I5I. http://ojs.uv.es/index.php/MCLM

ISSN $2386-8295$ 
RESUMEN

El estudio de fondos archivísticos procedentes de órdenes religiosas medievales ha permitido localizar un segundo fragmento de una Biblia castellana romanceada, procedente del monasterio jerónimo de Santa María de la Sisla (Toledo). Se trata de un bifolio del libro de los Salmos que perteneció al mismo códice que el fragmento de Ezequiel recientemente identificado $\left(=\mathrm{S}_{\mathrm{I}}\right)$. En este artículo se da cuenta del hallazgo, se describe el liber tradens precisando su significado y valor para asegurar las rentas del monasterio, se da razón de los fragmentos que transmite: parte de un bifolio en pergamino del s. XIII y el bifolio bíblico que le sirve de cubierta, incidiendo especialmente en la descripción de este segundo fragmento $\left(=\mathrm{S}_{2}\right)$. Seguidamente, se examinan las relaciones entre $\mathrm{S}_{2}$ y Esc. I-I-3, se ofrece una hipótesis de filiación y, finalmente, una transcripción paleográfica del texto.

PALABRAS CLAVE

Biblia romanceada; traducciones; fragmentos; crítica textual; codicología; jerónimos; monasterio de Santa María de la Sisla

Gemma Avenoza. 20I8. 'Salmos 32.II-36.7 y 78.25-8I.2: nuevos fragmentos de la Biblia castellana romanceada del Monasterio de Santa María de la Sisla', Magnificat Cultura i Literatura Medievals, 5: II5-I5I. (cc) Br

TABLA DE CONTENIDOS

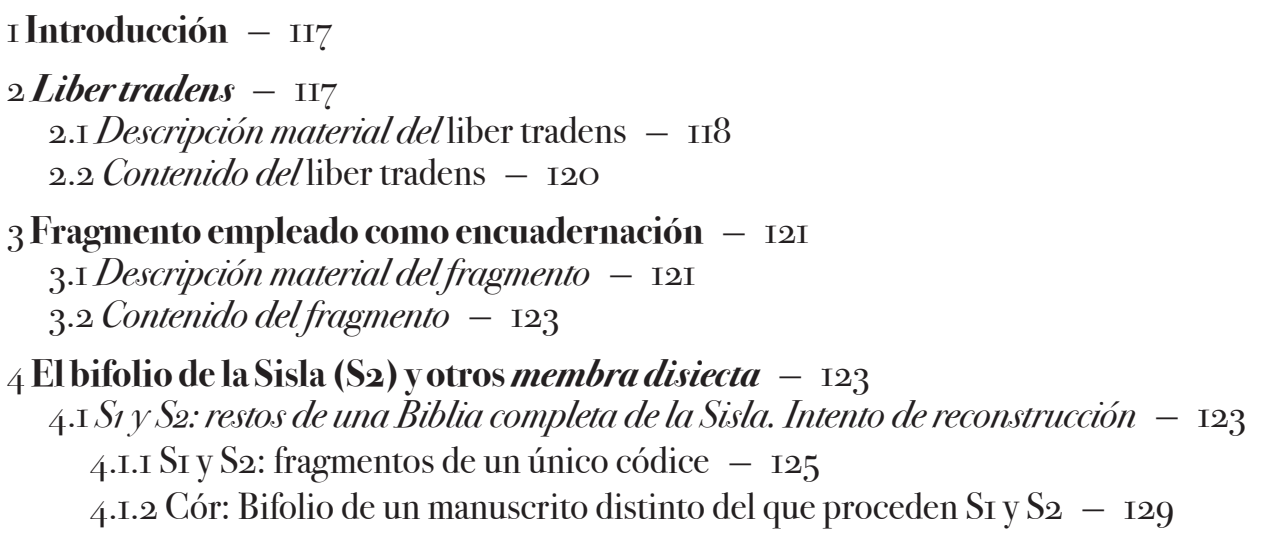

5 Relaciones textuales entre SI (Ezequiel ı6.25-18.30), S2 (Salmos 32.II-36.7 y 78.25-8I.2), Cór (Salmos 55.6-68.35y ro6.36-108.I2) y E $\mathbf{3}_{\mathbf{1}}$ (Biblia completa) - I3O

5.I Cór, $S_{1}, S_{2}$ y $E_{3}$ : : una misma traducción - 130 5.2 Relaciones entre $E_{3}, y S_{2}-133$

5.2.I $\mathrm{S}_{2}$ no copia $\mathrm{E}_{3}-\mathrm{I} 33$

5.2.I.I Lagunas - I33

5.2.I.2 Errores - I34

5.2.2 $\mathrm{E}_{3}$ no copia $\mathrm{S}_{2}-{ }_{1} 36$

5.2.2.I Lagunas - ${ }_{13} 6$

5.2.2.2 Variantes y errores (conjuntivos y separativos) en $\mathrm{S}_{2}$ y $\mathrm{E}_{3}{ }_{\mathrm{I}}-{ }_{13} 6$

5.2.3 Variantes o errores de menor entidad - 139

5.2.3.I Género y número - I39

5.2.3.2 Artículos, determinantes, preposiciones, pronombres, adverbios o conjunciones - I39

$5 \cdot 2 \cdot 3 \cdot 3$ Formas verbales -139

5.2.3.4 Errores por duplografía - 139

5.2.3.5 Onomástica y toponomástica - 139

6 Recapitulando - 139

7 Transcripción paleográfica de Sal. 32.II-36.7 y 78.25-8I.2 - I4O

7.I Normas de transcripción - 140

7.2 Texto: AHNClero Regular-Secular, L. 14734, cubiertas - I4O

7.2.I Fragmento A - I4O

7.2.2 Fragmento B - I45

8 Obras citadas - I 49 


\section{ə*⿻}

\section{Introducción}

La investigación en los fondos del Archivo Histórico Nacional ha permitido localizar e identificar un número importante de fragmentos de obras en lengua romance que fueron reutilizados como cubiertas o refuerzos de libros y legajos de contenido documental. Proceden, en mayor medida, de fondos que no han sido aún catalogados de forma exhaustiva; no por desidia, sino porque la cantidad ingente de fondos custodiados en los archivos no está en proporción al número de archiveros y de investigadores que pueden dedicarse a estas tareas y, por otro lado, porque los estudiosos que han tenido estos materiales en sus manos estaban más interesados en el contenido de los liber tradens que en los fragmentos en pésimo estado de conservación que los protegían.

Algunos proyectos han emprendido en los últimos años búsquedas sistemáticas de fragmentos de códices, como es el caso del dedicado a los fragmentos hebreos, liderado por Javier Del Barco en el AHN (LEGARAD II, cf. Nogal y Barco 2013 y Barco y Panizo 20Io); ${ }^{\text {B }}$ BITAGAP, que estudia fragmentos gallegos y portugueses en bibliotecas y archivos de España y Portugal; el que se ocupa de fondos bíblicos catalanes liderado por Jaume Riera y Pere Casanellas procedentes de los tribunales de la Inquisición de Barcelona y Valencia (Riera 2OI3; Casanellas 2OI4, 2OI5; Avenoza 20I8 BITECA: manid 5I48 y manid 5I5O); los estudios realizados sobre al Archivo de la Real Chancillería de Valladolid (Ruiz Asencio I998; Fradejas 20I5b); el proyecto de estudio de fragmentos hebreos reutilizados del Arxiu Històric de Girona, o los hallazgos de fragmentos en archivos catalanes de J. Antoni Iglesias-Fonseca (2009, 2OIO, 2000, y con Joan M. Perujo 20I4). Otros hallazgos han surgido de forma individual, como el de Javier Rodríguez Molina (20I6) de un fragmento de la Catena aurea del s. XIV, o bien han sido fruto de la serendipia, al investigar fondos monásticos buscando información sobre un relevante monje jerónimo, Gonzalo de Ocaña, como ha sido el caso del hallazgo de fragmentos bíblicos castellanos (Avenoza 20r7 y Avenoza en prensa a y b).

En este estudio se describe, analiza y edita un bifolio de pergamino procedente de una Biblia traducida al castellano que perteneció al mismo códice del que hace poco se halló otro bifolio con texto del libro de Ezequiel (editado y estudiado en Avenoza 20I7). Ambos se han localizado en documentación procedente del monasterio jerónimo de la Sisla.

\section{Libertradens}

Llamamos liber tradens al volumen que de forma accidental ha servido como elemento transmisor de uno o más fragmentos de una obra anterior, que fueron empleados como encuadernaciones, refuerzos de la estructura, o que se hallan insertos de cualquier otra forma en el volumen.

I. No se pretende enumerar todos los proyectos sobre fragmentos, cuya historia se remonta en España a las primeras décadas del s. Xx. Para una breve aproximación metodológica, de fuentes y materiales véanse por ejemplo Pellegrin (I980), Alturo (I990, I999) e Iglesias-Fonseca (20I3), o las publicaciones online de Fradejas Rueda (20I5a). Para una descripción actualizada de este tipo de investigaciones en el ámbito de los fragmentos de códices musicales hispánicos véase Andrés Fernández y Martí Martínez (2OI7), trabajo que incluye una extensa bibliografía sobre el estudio de fragmenta y membra disiecta. 
En el caso que nos ocupa, el fragmento castellano servía de cubierta al liber tradens y ha sido posible estudiar conjuntamente ambas unidades y entender mejor de ese modo sus orígenes y los avatares de su transmisión hasta nuestros días. ${ }^{2}$

\section{I Descripción material del liber tradens}

El fragmento bíblico objeto de este estudio se había empleado como encuadernación de un legajo hoy en el Archivo Histórico Nacional de Madrid, signatura: Clero Regular-Secular libro I4734. Olim № I5 legajo $3{ }^{\circ}$ cajón 2; Tdo I39. ${ }^{3}$

El documento notarial pertenecía al archivo del monasterio de Santa María de la Sisla. Se empleó un pergamino muy claro y de buena calidad (dispuesto CPPC) para transcribir el documento fechado entre el I9-O9-I496 y el IO-IO-I 497 en letra gótica redonda cuidada, salvo las autentificaciones notariales, escritas con letra cursiva y más personal.

Procede de la zona de influencia del monasterio, en la provincia de Toledo, dado que se trata de un documento dado en Maqueda ante el escribano Ximeno de Burgos. Llegó al AHN junto con la documentación procedente del monasterio a raíz de la desamortización de los bienes eclesiásticos del s. XIX, y se encuentra en perfecto estado de conservación. ${ }^{4}$

En este documento se copian los almotaces de unas tierras vinculadas al monasterio, según el título escrito a tinta en un tarjetón de pergamino que estaba cosido sobre la cubierta anterior del volumen (de IO4 X I7O mm, que actualmente se ha separado de la cubierta):

Sisla Almotaçes Sto Domingo. | Almotazes delas tierras de St. Ana en Sto. Do | mingo y [...]us lugares y Oliuas en Torrijos | Maqueda y su tierra que se hiço el [a]ño de I496 | Ay otro Almocaz que se hiço A año de I473.

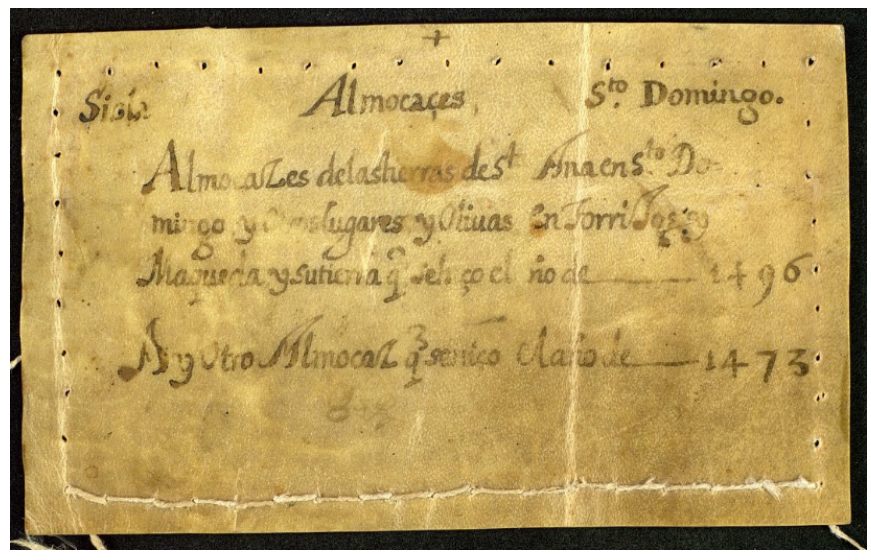

Imagen I: Tarjeta con el título (recto). AHN, Clero Regular-Secular libro I $4734^{5}$

2. Cuando se encuentra un fragmento en un archivo o biblioteca, son muchas las ocasiones en las que no se tiene dato alguno acerca de su liber tradens, y esta falta de información impide a los investigadores obtener datos sobre su procedencia.

3. La primera signatura antigua es parcialmente ilegible y se encuentra anotada en el margen superior del pergamino que sirve como cubierta; la segunda, a lápiz rojo, está en el interior de la cubierta anterior, y hace referencia a su procedencia toledana.

4. El estudio de Caballero García (2005) ilustra sobre cómo se desarrolló el traslado de fondos de las instituciones religiosas y su cambio de titularidad a través del examen de los fondos de la provincia de Guadalajara. Sobre la creación de la sección de Clero en la que se halla el fragmento estudiado véase Cruz (2003).

5. (C) Ministerio de Cultura y Deporte, Archivo Histórico Nacional. Se aplica a todas las imágenes provenientes del 
Este tarjetón, a su vez, es parte de un pergamino documental referente a asuntos de un monasterio, en el que constan como testigos vecinos de San Martín de Valdeiglesias (Madrid), población situada lindando con Ávila y Toledo, ${ }^{6}$ perteneciente a la diócesis toledana. Está copiado con una letra gótica cursiva influida por la cortesana, probablemente del primer cuarto del siglo XV, como sugiere su semejanza con la escritura de un documento procedente de San Martín de Valdeiglesias fechado el 26/O5/I4I4 (AHN Clero Regular-Secular, Car. I396 N. 5). El texto ocupa el lado carne y sobre la parte posterior (lado pelo), que estaba en blanco, se anotó el título del libro de la Sisla.

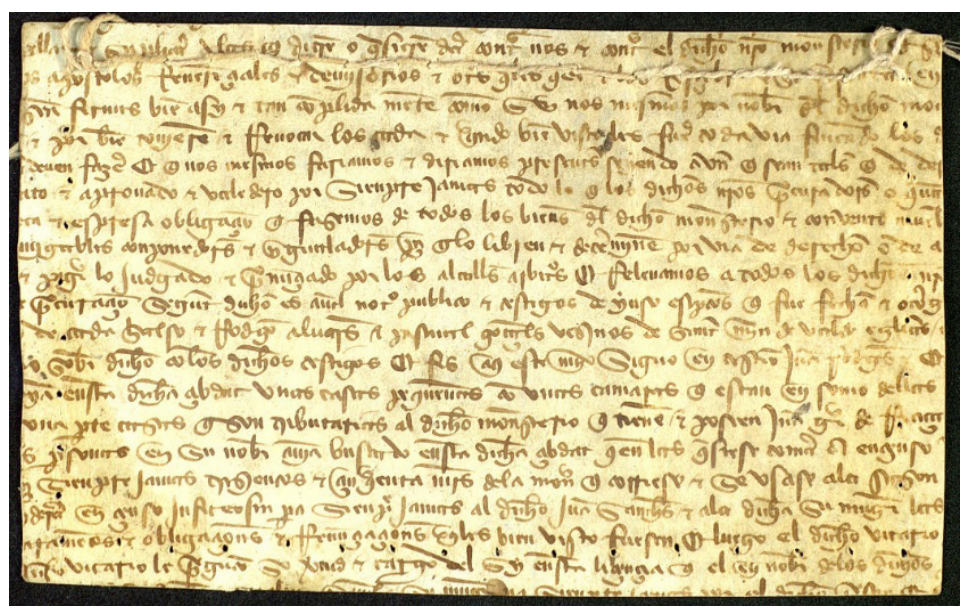

Imagen 2: Tarjeta con el título (verso). AHN. Clero Regular-Secular libro I4734

El cuerpo del libro conserva la foliación original en cifras romanas en el margen inferior de los folios, a unos 20 mm de la línea de justificación vertical derecha: ff. j-xxj + I s/n (último de la unidad documental). El documento se copió sobre tres cuadernos perfectamente preparados y señalados con signaturas de bifolio alfanuméricas en el ángulo inferior derecho de los folios, en la primera parte de los pliegos: [a] aij aiij aiiij; bj bij biij biiij; cj cij [ciij].

El libro mide 279/289 x 200 mm (aprox.), medidos en el plano anterior de la encuadernación. La hoja mide $272 / 277$ de alto por I9I/I94 de ancho y la caja de escritura a línea tirada tiene márgenes generosos: $\left(27^{+} \mathrm{I}_{95}+5 \mathrm{O}\right) \times(2 \mathrm{I}+\mathrm{I} 4 \mathrm{I}+3 \mathrm{I}) \mathrm{mm}$ (medidos en el f. 3$)$. El estado de conservación es excelente.

La escritura deja en blanco la primera línea de las 42 del pautado, y la justificación incluye líneas de guía para los renglones, que se han trazado con la ayuda de perforaciones situadas en el margen derecho y que prácticamente dibujan una línea recta. Las que marcaban las líneas fundamentales de la caja de escritura estaban cerca de los márgenes y han desaparecido. Para marcar la justificación se empleó una punta de plomo que apenas se distingue. El esquema se corresponde con el más sencillo para una columna, donde las líneas fundamentales de la justificación atraviesan totalmente el folio y llegan hasta los márgenes.

AHN aquí reproducidas.

6. Madoz (I849: XV, 273-74 S/v Valdeiglesias, San Martín de): part. jud. de entrada en la prov. y aud. terr. de Madrid, c. g. de Castilla la Nueva, dióc. de Toledo. Madoz no menciona el monasterio jerónimo, pero sí un convento de monjas dentro de la población (ibid. XII, 760 s/v Pelayos). 
El documento se inicia con una linea en letra gótica fracta de módulo mayor al del texto, y la decoración se completa con la presencia de calderones en tinta roja y con titulillos en el margen superior, en la misma tinta del texto.

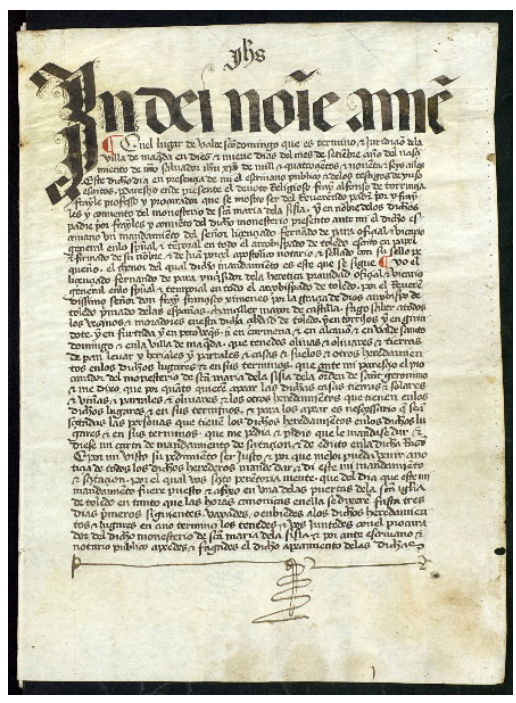

Imagen 3: AHN. Clero Regular-Secular libro I4734, f. I ${ }^{\mathrm{r}}$

El documento notarial lleva anotada en columnas laterales la suma de las tierras y de los olivares objeto del apeo, y en los márgenes hay manículas señalando pasajes, correcciones y adiciones.

En la parte inferior de lo que sería el lomo estaba pegada una etiqueta de papel con la signatura actual. En el centro de las cubiertas se aprecian perforaciones como las que quedarían tras haber retirado una pieza de piel de sujeción (hoy desaparecida), por la que pasaran los hilos de las costuras de los cuadernos. Esas tres perforaciones concuerdan con los tres cuadernos en los que está copiado el documento. En las cubiertas se ven algunas anotaciones que, o bien se relacionan con la tipología del documento que protegen "Almotaces", o bien son operaciones matemáticas.

El almotaz se transformó en liber tradens de tres fragmentos de pergamino con texto más antiguo. Dos de ellos proceden de un manuscrito latino del s. XIII. El más pequeño es un menudo rectángulo que estaba sujeto en la parte interior de la cubierta por tres tiras de piel, dispuestas del mismo modo que algunas de las que sujetan los nervios a las cubiertas. Este pequeño trozo de pergamino se separó de la cubierta en la intervención del departamento de restauración de 20r8. El segundo fragmento del manuscrito latino tenía como función proteger exteriormente el segundo cuaderno del libro de la Sisla, y conserva parte de dos columnas de un bifolio, con fragmentos de obras de Gregorio Magno y Beda el Venerable (Avenoza en prensa a).

El membrum disiectum de mayor entidad es un bifolio de pergamino reutilizado, procedente de un códice bíblico de generosas dimensiones, que se empleó como encuadernación del almocaz y que constituye la materia principal de este estudio.

\subsection{Contenido del liber tradens}

Almotaces de las tierras de Maqueda. El documento es un apeo de tierras de I 496 elaborado para establecer a quién corresponde la propiedad de las mismas, basado en anteriores almotaces (o 
almocaces) de I473, en los que se definían sus lindes y extensión y producción de las tierras. ${ }^{7} \mathrm{Se}$ trata, por lo tanto, de un documento de notable importancia para el monasterio, pues permitía mantener el control de la producción y los ingresos que se derivaban, eliminando cualquier disputa que pudiera surgir en cuanto a los lindes.

\section{Fragmento empleado como encuadernación}

\section{I Descripción material del fragmento}

El pergamino empleado para la encuadernación se ha situado mostrando en el exterior el lado pelo (PCCP) y con el texto invertido, dificultando distinguir la escritura original. Está deteriorado por el roce y tiene roturas en el centro del pliego (debidas a desgaste y a la acción de bibliófagos), en el interior de algunas columnas y en los márgenes, que actualmente han sido restauradas con añadidos de papel japón.

Como era habitual, para ajustar el pergamino al tamaño del legajo, se doblaron las partes sobrantes del bifolio hacia la parte interior y se fijaron con costuras en forma de " $\mathrm{X}$ ", dos en cada cubierta: las delanteras visibles en el recto y las posteriores en el verso, cuyos hilos han sido retirados actualmente.

Tras las intervenciones de 20I7 y 20I8, aún queda pendiente reparar algunas roturas y someter el pergamino a un tratamiento que permita desdoblarlo sin peligro de posterior deterioro y elimine las arrugas.

La letra tiene las características propias de la gótica redonda de mediados del s. XV. Aunque no se trata de la misma mano, tiene características muy semejantes a la de los códices BNE MSS/9243, MSS/ 9244 (fechado en I450), ${ }^{8}$ MSS/IO8I 4 de I 434 y MSS/ 3369 de I 455 citados por Millares Carlo

7. Un almotaz es una medida fiel de un terreno y del cálculo de su producción basado en los apeos que establecen de forma fidedigna los límites de las tierras, (Fuentes Sanz 20I5; López Villalba 2002: 587-88; García Larragueta I987). Los tratados, hasta al menos el s. XIX, insisten en la importancia de realizar de forma periódica apeos de las tierras, dado que la pérdida de los lindes no lleva a otra cosa que a pleitos: "que para la averiguacion de sus antiguas, y verdaderas lindes proceden pleytos, que dàn que merecer, y gastar” Sánchez de Villajos (I752: 86). En esta misma obra se describe el procedimiento del apeo, con la elección de los apeadores "Presenta el que hace el apèo al señor Juez los Apeadores, que antiguamente vieron, y supieron como estaban las lindes, y la heredad; y mientras mas ancianos en el conocimiento, mas credito se les dà ... Estos han de ser hombres de mucha verdad” (ibid. 9I). Describe el anuncio público de que se llevará a cabo, la autoridad que lo vigila, los documentos que deben presentarse para el mismo y la periodicidad con la que debe realizarse: "Qualquier apéo debe ser judicial para la formalidad; y siendo [p. 92] muchas tierras, ò Mayorazgos, debe ser con licencia del Consejo Real de Castilla, que nombre Juez que vaya, ò assiste la Justicia Ordinaria de donde se hace, y el Escribano del Numero. No pueden dàr principio, sin tener presentes las Escrituras de compra anteriores à los apèos; y yà para este dia, y hora se les ha avisado à los dueños de las heredades, que lindan con las que se vàn à buscar, sabiendo quien son; dandoles tiempo, y termino para que busquen sus Escrituras, y siempre acudan, por lo mucho que cuesta el hacer un apèo; pero no sabiendo quienes son, mandan poner Edictos, y Pregones con sus terminos; señalando el dia, y la hora que se ha de [p. 93] dàr principio, y en què parage, para mayor acierto, y claridad de todos. Y porque los apeos se deben hacer de diez en diez años, y muchas veces sin hacerlos, passan de ıoo; de aqui procede el perderse las heredades, porque no puede haver Apeadores, que digan en tan largo tiempo por donde iban las lindes, ni aun tal vez como se llaman los parages, mojones, ni otras cosas. Y porque ir recusando à unos, y nombrando à otros, por travesura de Procuradores, y meterlo à barato, ò à pleyto, quando suelen ser lances estos, que apenas acontece haver dos, ò tres hombres ancianos, que pueden serlo; y èstos tal vez estàn caducos, ò trascordados; [p. 94] pues no es como recusar à un Escribano, que à falta suya hay otros infinitos.” (ibid. 9I-94).

8. Este manuscrito contiene la traducción castellana del Llibre dels àngels de Francesc Eiximenis, traducido por el 
(I983: i, 2II-I2) como ejemplo de la "escritura semigótica o redonda [que] disputó durante el siglo XV a la cursiva el terreno librario para los textos romances" y cuyas formas más significativas, tal y como las describe Millares, se hallan en este fragmento.

Cada salmo está introducido por una rúbrica en tinta roja y una inicial de 304 unidades de pauta con decoración filiforme sencilla, alternando en la letra el rojo y el azul y en la decoración el color complementario. Los calderones, en tinta roja, tendrían como función marcar cambios de párrafo o pausas de la lectura (Bobichon $2009 \mathrm{~s} / \mathrm{v}$ pied-de-mouche).

No lleva titulillos en los márgenes superiores como los que se encuentran en el bifolio de esta misma biblia en el que se copiaba el fragmento de Ezequiel (Avenoza 20i7: 294).

Los folios del fragmento reutilizado miden aproximadamente $398 \times 25^{8} \mathrm{~mm}$. La caja de escritura, de 26I x I80 mm, está distribuida en dos columnas de $80 \mathrm{~mm}$ separadas por un intercolumnio de unos $2 \mathrm{O} / 22 \mathrm{~mm}$. El pautado se realizó a punta seca, que en la parte interior parece repasada a punta de plomo. No se distinguen líneas de guía para los renglones, y la caja de escritura tiene 46 líneas escritas más la primera de la pauta que se ha dejado en blanco. Aparentemente se trata del esquema de justificación más sencillo para dos columnas, en el que las líneas fundamentales del pautado llegan hasta los límites del folio.

La foliación original conservada (f. I $=$ ccclxvj y f. $2=$ ccclxxvij) indica que se trata posiblemente del bifolio exterior de un senión, aunque no se ve reclamo alguno en su margen inferior. No es la primera vez que encontramos biblias romanceadas copiadas en cuadernos de seis bifolios, concretamente, dos de los códices de los que tenemos noticia y que transmiten, como se verá más adelante, esta misma traducción castellana que este fragmento: el fragmento de Córdoba (Cór) y Escorial I-I-3 $\left(=\mathrm{E}_{3}\right) .{ }^{9}$ Cór era el bifolio exterior de un senión y E ${ }_{3}$ es un manuscrito formado básicamente por seniones. ${ }^{10}$ A partir de esta coincidencia formal con otros manuscritos de época y formato semejante y que copian la misma traducción, no es descabellado pensar que también eran seniones los cuadernos que formaban la Biblia de la Sisla.

El fragmento ha sido incorporado a la base de datos sobre testimonios de la literatura medieval castellana BETA, con el identificador manid 5936, y su descripción completa podrá consultarse en breve en la web del proyecto PhiloBiblon/BETA.

monje bernardo Fr. Miguel de Cuenca y por el monje jerónimo Fr. Gonzalo de Ocaña, que fue prior de Santa María de la Sisla.

9. Téngase en cuenta que en los romanceamientos bíblicos castellanos no se debe identificar códice con traducción, puesto que muchos manuscritos están compuestos a partir de traducciones distintas, tal y como exponen Enrique-Arias y Pueyo Mena (20I7: 65-66) para E4. Ahora bien, $\mathrm{E}_{3_{1}}$ es una de las excepciones, puesto que se trata de una traducción unitaria, en la que todos los libros surgieron de la mano de un único traductor, excepción hecha de la parte final (conocida bajo las siglas $\mathrm{E}_{3} \mathrm{y}_{3}$ ) que corresponde a los libros I-II Macabeos, aspecto no poco relevante y singular en el ámbito de las biblias romanceadas (vid. Pueyo Mena y Enrique-Arias 20I3).

Io. Existe una amplísima bibliografía sobre E3 y la traducción que transmite, imposible de reproducir aquí, por lo que remito al apartado "Bibliografía” de Bibliamedieval.es. Sobre la historia de E3 y su descripción material vid. Avenoza (2OII: I3I-46). Los manuscritos bíblicos se citan mediante las siglas habituales en los estudios sobre biblias castellanas romanceadas: E3 = Esc. I-I-3; E5 = Esc. I-I-5; E6 = Esc. I-I-6; E8 = Esc. I-I-8; E4 = Esc. I-I-4; EV = Évora, Biblioteca Pública, ms. CXXIV/I-2; EV2 = Évora, Archivo Distrital Fundo Notarial de Évora, leg. 836; Oxford = Oxford, Bodleian Library Canon Ital. I77; BNM = BNE MSS/IO288; RAH = RAH Cód. 87; Arrag = Madrid, Alba, Biblia de Arragel; Cór = Córdoba, Archivo de la Catedral Ms. I67. Para las distintas traducciones que transmiten estos manuscritos y sus relaciones remito al esquema publicado por Pueyo Mena (20o8), actualizado en http:// bibliamedieval.es/relaciones.pdf (pendiente de incorporar Oxford, SI y S2). Los subíndices que siguen a cada sigla hacen referencia a las distintas traducciones que cada códice contiene. 


\subsection{Contenido del fragmento}

En Avenoza (20I7: 292) se denominó al primer fragmento de la Biblia de la Sisla localizado como $\mathrm{S}_{\mathrm{I}}$, de modo que nos referiremos a este como $\mathrm{S}_{2}$. Tal y como se ha dicho, es el bifolio exterior de un cuaderno y contiene dos fragmentos del libro de los Salmos:

Fragmento A: Sal. 32.II-37.6 (f. I $^{\text {ra-vb }}=$ ccclxvj foliación antigua). Inc.: conel sennor \& gozad los justos \& can $\mid$ tad todos los derecheros de coraçon... Expl.: la tu lj $\mid$ mosna es commo los montes fuertes | los tus juyzios commo el abismo.

Fragmento B: Sal. 78.25-8I.2 (f. $2^{\text {ra-bb }}=$ ccclxxvij foliación antigua). Inc.: [...] a fartura | fizo mouer solano por | el çielo \& fizo gujar con su fortaleza... Expl.: Cantad a dios sobre nuestra] | fortaleza tanned a dios [...].

Se trata de la misma traducción del libro de los Salmos transmitida por $\mathrm{E}_{3_{\mathrm{I}}}$ y por el fragmento de la Catedral de Córdoba (Cór), con poquísimas variantes en los textos que se pueden comparar (vid. Avenoza 20II: 3I5-I9, 349-54 y Bibliamedieval.es).

Como se verá seguidamente, $S_{\text {I y }} \mathrm{S}_{2}$ no proceden del mismo códice que Cór, aunque todos ellos transmiten la misma traducción que $\mathrm{E}_{3_{i}}$.

\section{${ }_{4}$ El bifolio de la Sisla (S2) y otros membra disiecta}

\section{I S1 y S2: restos de una Biblia completa de la Sisla. Intento de reconstrucción}

Este bifolio de Salmos ( $\mathrm{S}_{2}$ ) y el de Ezequiel ( $\mathrm{S}_{\mathrm{I}}$ ) antes mencionado proceden de un mismo manuscrito que se encontraba en el monasterio de Santa María de la Sisla al menos hacia I497. La distancia temporal entre los libri tradentes de $\mathrm{S}_{\mathrm{I}}$ (I5I5) y $\mathrm{S}_{2}$ (I495), el que traten de territorios diferentes y hayan sido expedidos por distintos notarios, descarta que hayan sido encuadernados fuera del monasterio, es decir, mientras se encontraban en manos de los fedatarios que les dieron su forma administrativa. Sabemos que era un uso habitual el reaprovechar pergamino procedente de códices fuera de uso como encuadernación de documentos (Ruiz Asencio I998: I78-8I) y a través del estudio de la documentación de la Sisla del AHN (Madrid: Archivo Histórico Nacional) se ha verificado que el entorno del monasterio jerónimo seguía esta costumbre (Avenoza 2OI7: 29O-I).

Sin abandonar la documentación relacionada con la Sisla encontramos un ejemplo de la vinculación de pergaminos reutilizados como encuadernaciones con los emisores de la documentación. En el archivo segoviano AAHS (Bernuy de Porreros, Segovia: Archivo Antonio Hidalgo Sánchez) se conserva una importante documentación notarial procedente de la Sisla, que se transmitió entre los distintos poseedores que tuvo el Monasterio tras la desamortización (Hidalgo-Pardos 20I6: 5${ }^{\mathrm{I}-4}$ ). ${ }^{\mathrm{II}}$ En este archivo privado se hallan al menos ocho membra disiecta latinos empleados como encuadernaciones. En tres de esos documentos interviene Antón Suárez de Camargo, clérigo cura de la parroquia de San Esteban de Corullón (León). Observando la tipología a la que pertenecen los fragmentos reutilizados para encuadernar los documentos, se advierte que todos están relacionados con las funciones litúrgicas propias de una parroquia, pero que en el momento en el que se redactan los documentos ya no servían para el culto. ${ }^{12}$

II. Estas imágenes han sido proporcionadas por el responsable del archivo, Juan Antonio Hidalgo Pardos a quien agradezco muy especialmente las facilidades para trabajar con los fondos del AAHS.

I2. El deterioro del códice bíblico (imagen 4), la posible dificultad que encontrara el clérigo para leerlo por una parte 


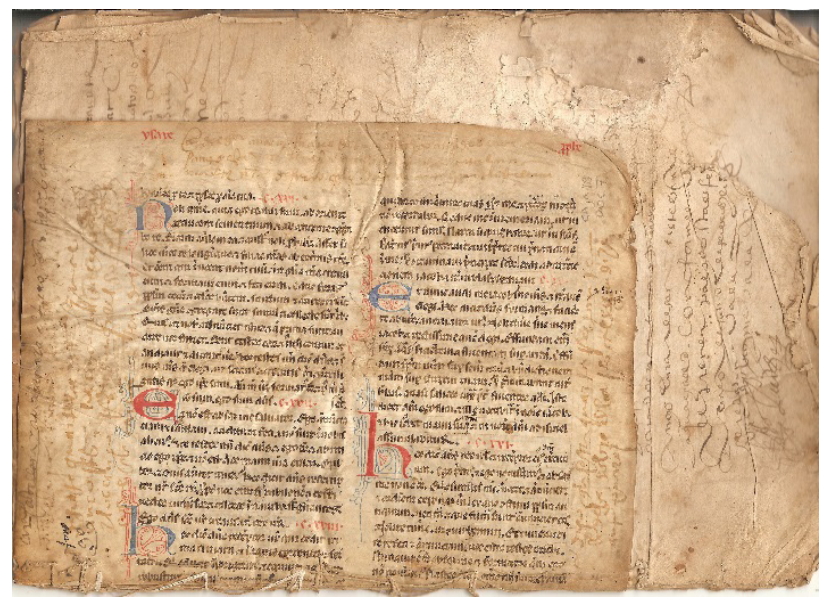

Imagen 4: AAHS. Caja No I8 doc. 7 Biblia, Isaías. (C) Archivo Antonio Hidalgo Sánchez

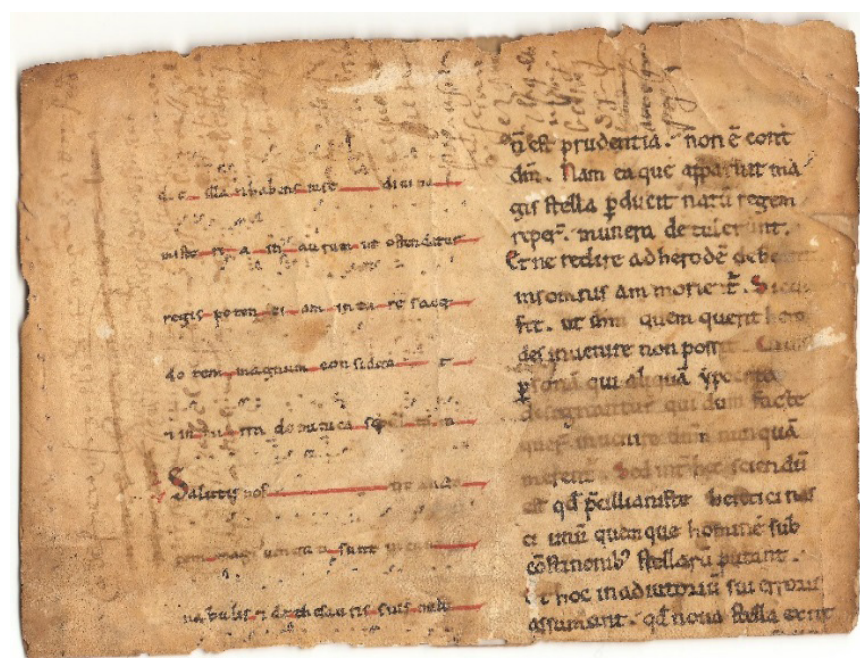

Imagen 5: AAHS. Caja № I8 doc. 8 Breviario ciscerciense primitivo. (C) Archivo Antonio Hidalgo Sánchez

y, los cambios que se sucedieron en el breviario (imágenes 5 y 6 ) hacen de estos documentos, propios de una biblioteca parroquial, candidatos a ser descartados y reutilizados. 


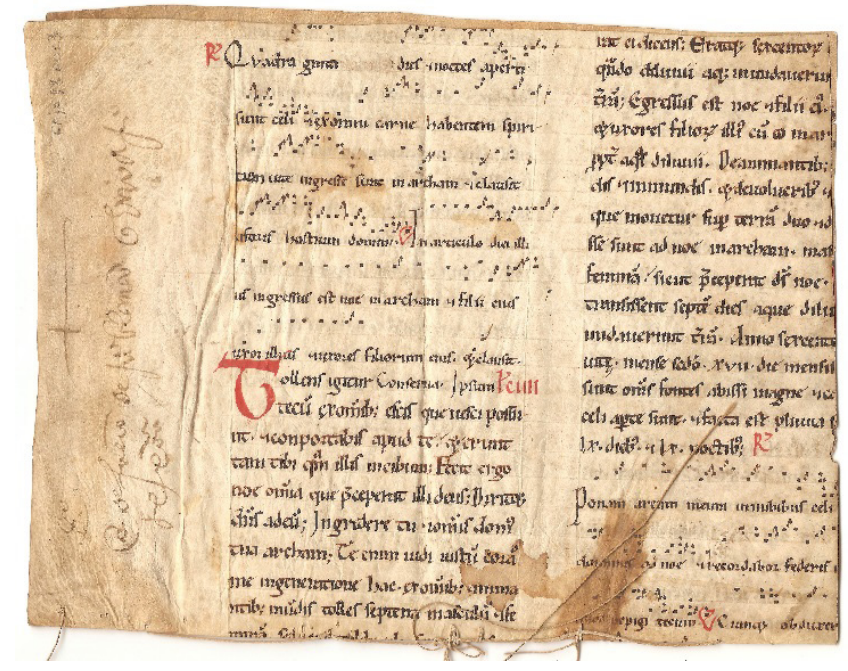

Imagen 6: AAHS. Caja No I8 doc. 3 Breviario ciscerciense primitivo (C) Archivo Antonio Hidalgo Sánchez

4.I.I $\mathrm{S}_{1}$ y $\mathrm{S}_{2}$ : fragmentos de un único códice

Los bifolios $\mathrm{S}_{\text {I y }} \mathrm{S}_{2}$ servían de encuadernación a sendos legajos del AHN y, gracias a la intervención de sus servicios de restauración, han sido separados de sus respectivos libri tradentes y consolidados, como puede verse en las imágenes siguientes, que han facilitado mucho el estudio de los textos.

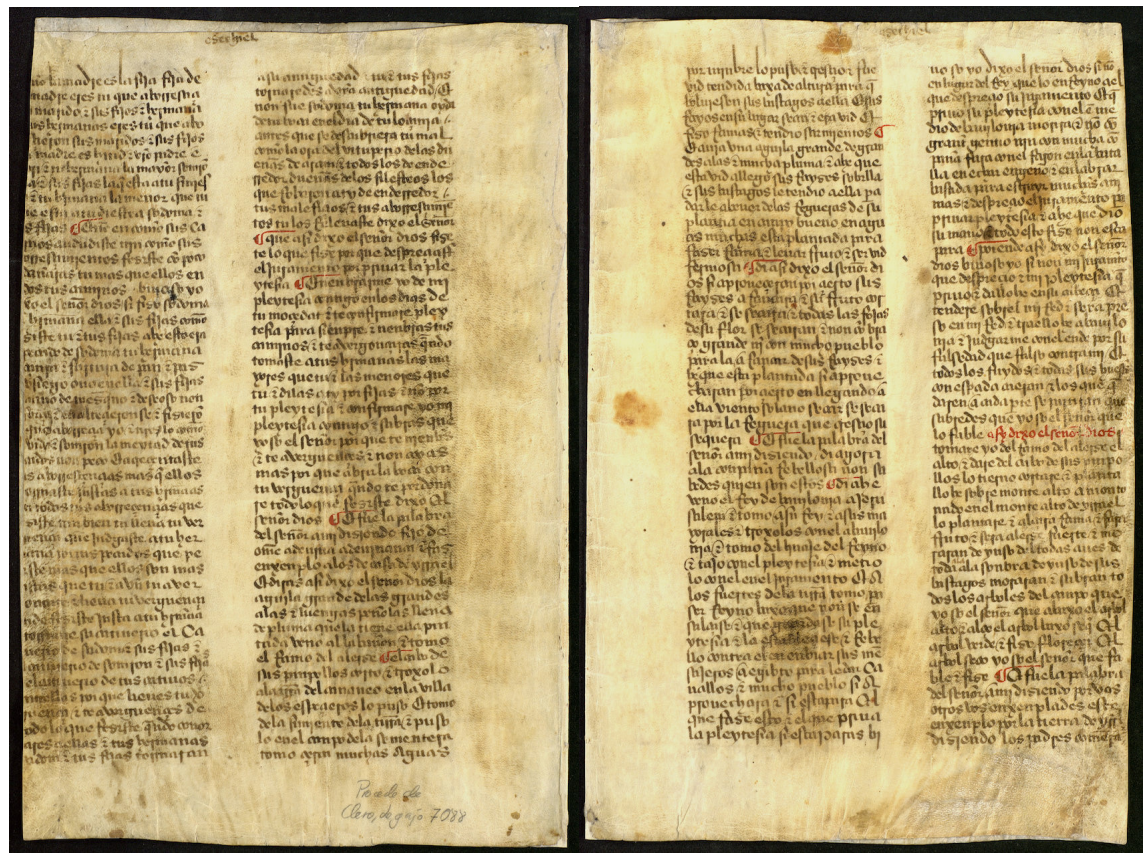

Imagen 7: $\mathrm{S}_{\text {I }}\left(\mathrm{ff}\right.$. $\left.\left[\mathrm{I}^{\mathrm{V}}-2^{\mathrm{r}}\right]\right)$. AHN Clero Regular-Secular 7088 doc. sin numerar 


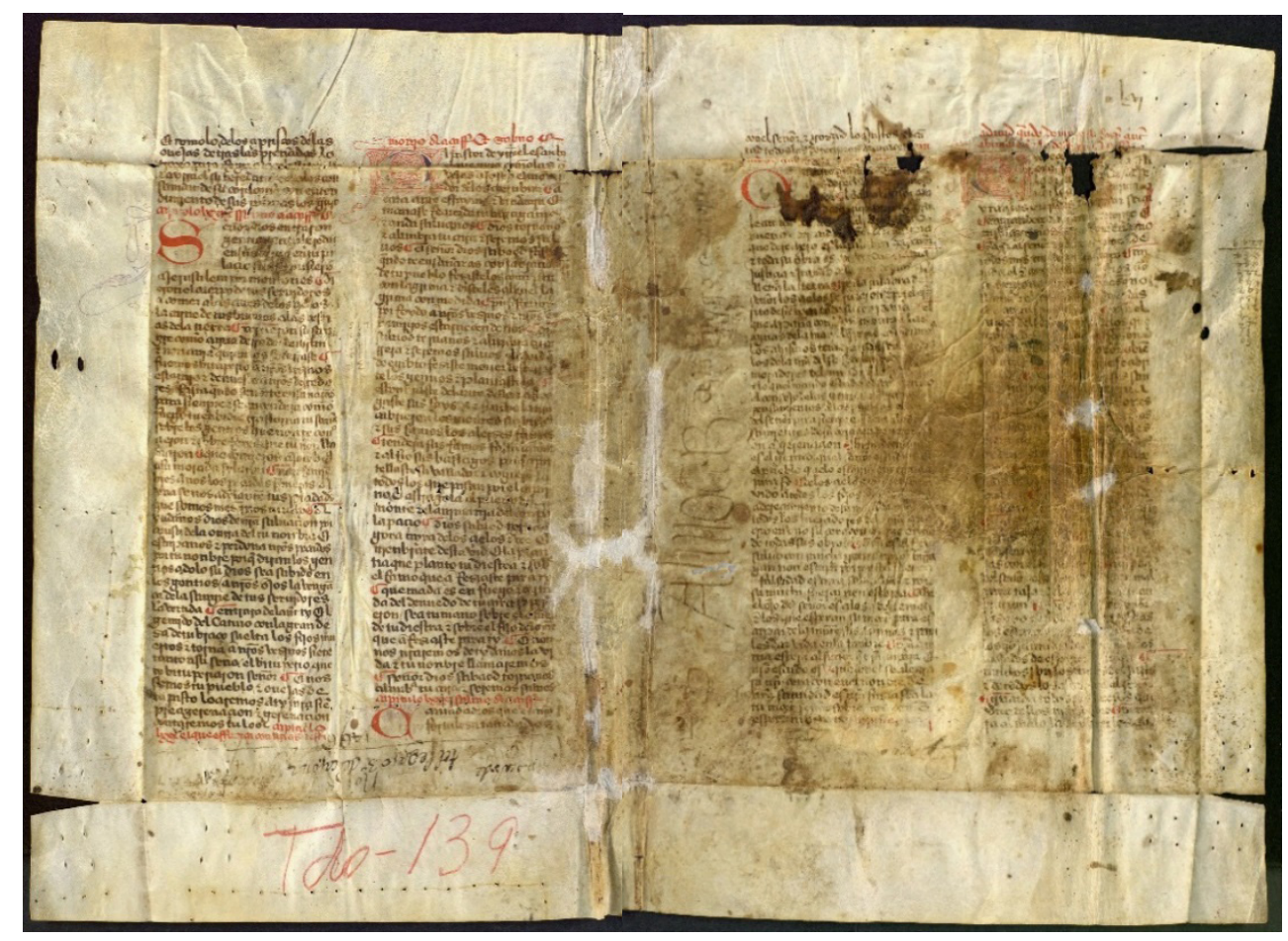

Imagen 8: $\mathrm{S}_{2}$ (parte exterior del bifolio: ff. ccclxxvij y ccclxvj'). AHN Clero Regular-Secular Libro I4734

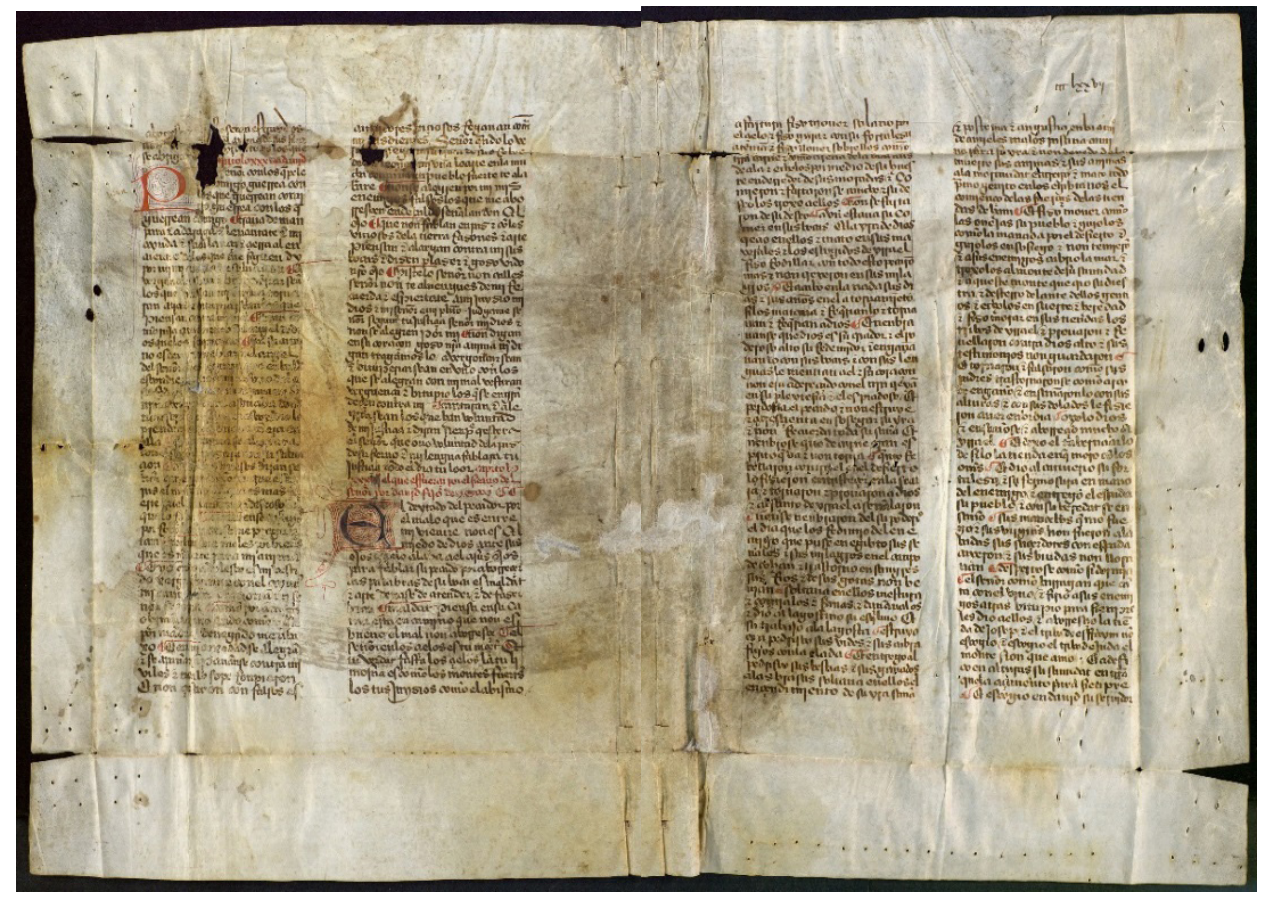

Imagen 9: $\mathrm{S}_{2}$ (parte interior del bifolio: ff. ccclxvj ${ }^{\mathrm{v}}$ y ccclxxvij ${ }^{\mathrm{r}}$ ). AHN Clero Regular-Secular Libro I4734 


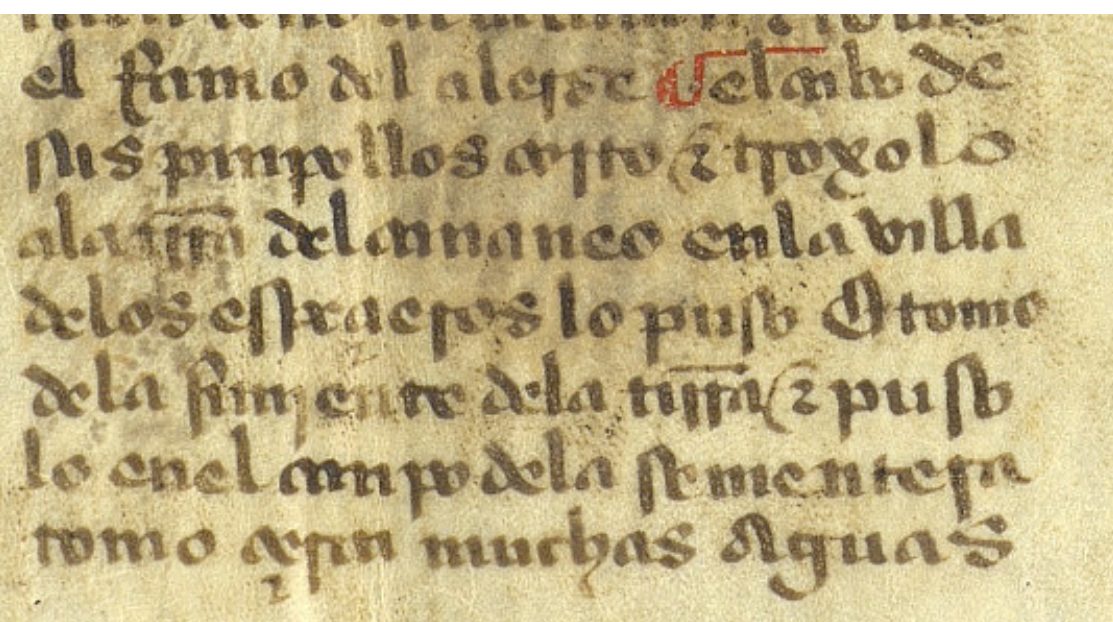

Imagen IO: Si f. [I] ${ }^{\mathrm{vb}}$ detalle. AHN Clero Regular-Secular 7088 doc. sin numerar

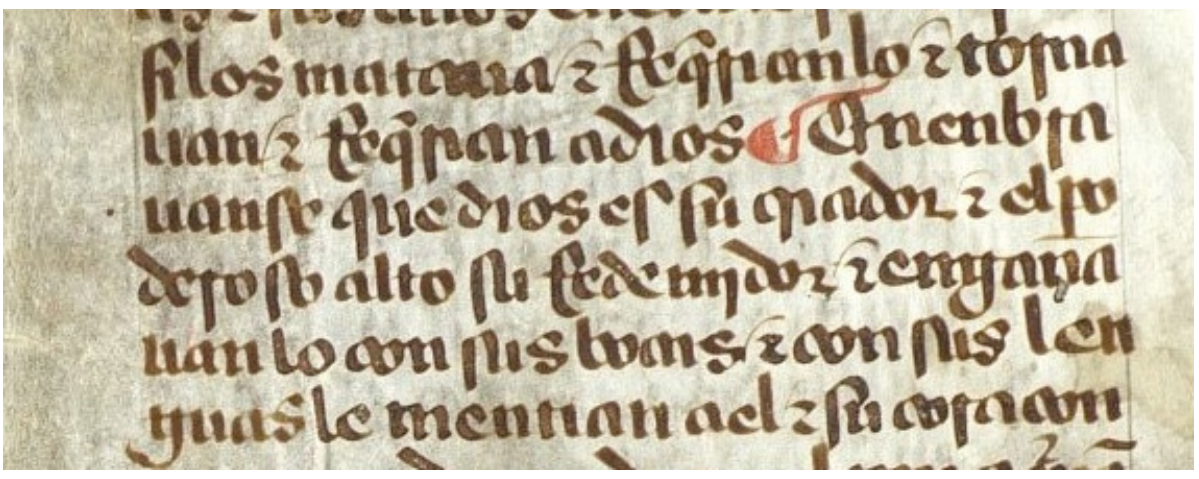

Imagen II: S2 f. ccclxxvij ${ }^{\text {ra }}$ detalle. AHN Clero Regular-Secular Libro I4734

Más allá de las semejanzas que se advierten a simple vista, el examen de la materialidad confirma que ambos bifolios, SI y S2, proceden del mismo códice.

\begin{tabular}{|c|c|c|}
\hline & $\mathrm{S}_{\mathrm{I}}$ & $\mathrm{S}_{2}$ \\
\hline Bifolio & central de un cuaderno & exterior de un cuaderno \\
\hline Disposición pergamino & CPPC & PCCP \\
\hline Dimensiones del bifolio & $3^{\mathrm{I}} 4 / 3^{19} \times 447 / 45^{8} \mathrm{~mm}$ & $398 \times 516 \mathrm{~mm}$ aprox. \\
\hline Dimensiones del folio & $3^{1} 4 / 319$ x $218 \mathrm{~mm}$ aprox. & $398 \times 25^{8} \mathrm{~mm}$ aprox. \\
\hline Dimensiones de la caja de escritura & $267 / 265 \times 184 \mathrm{~mm}$ & 261 X I80 mm \\
\hline Anchura columna & $8 \mathrm{o} / \mathrm{8}_{4} \mathrm{~mm}$ & $80 \mathrm{~mm}$ \\
\hline Anchura intercolumnio & $20 \mathrm{~mm}$ & $2 \mathrm{O} / 22 \mathrm{~mm}$ \\
\hline Núm. líneas escritas & $47 / 48$ & 47 \\
\hline Uso de la primera línea de pauta & $\begin{array}{l}\text { la escritura se dispone debajo de la primera } \\
\text { línea de pauta }\end{array}$ & $\begin{array}{l}\text { la escritura se dispone debajo de la primera } \\
\text { línea de pauta }\end{array}$ \\
\hline Proporción & $\begin{array}{l}\text { I, } 448 \text { (entre el rectángulo de la fórmula a x a } \sqrt{2} \\
\text { y el doble rectángulo de Pitágoras) }\end{array}$ & $\begin{array}{l}\text { I, } 45 \text { (entre el rectángulo de la fórmula a } \mathrm{x} \text { a } \sqrt{2} \\
\text { y el doble rectángulo de Pitágoras) }\end{array}$ \\
\hline
\end{tabular}


Ignoramos si el manuscrito estaba compuesto íntegramente de pergamino o sus cuadernos tenían los bifolios interior y exterior de este material y el resto era de papel. La disposición del pergamino en los bifolios conservados responde a la estructura PCCP (en el bifolio exterior) y CPPC (en el bifolio interior) se corresponde con la que se encontraría en seniones constituidos íntegramente de pergamino cumpliéndose, como es habitual, la ley de Gregory. También sería la disposición normal que se halla en los cuadernos mixtos compuestos de pergamino y papel:

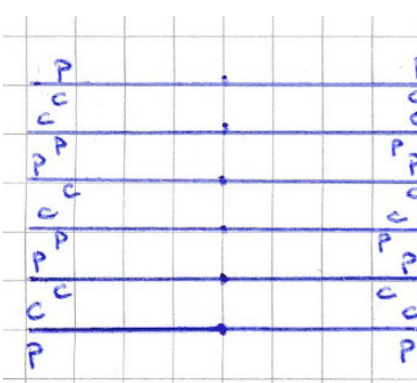

Imagen I2: Senión de pergamino

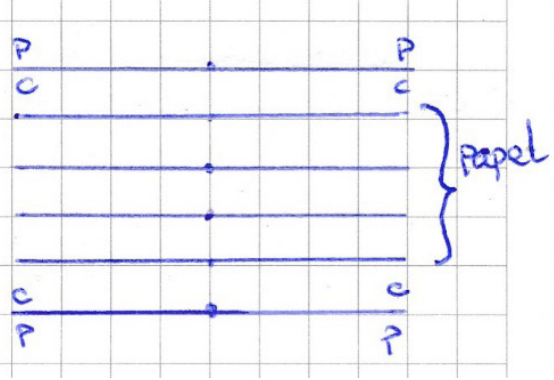

Imagen I3: Senión mixto

Al tratarse de bifolios con los márgenes recortados, solamente se pueden comparar las dimensiones y la distribución de los elementos de la caja de escritura. La altura y la anchura de la caja oscilan ligeramente entre una altura máxima de $267 \mathrm{~mm}$ (SI) y una mínima de $26 \mathrm{I}$ mm ( $\mathrm{S}_{2}$ ), y lo mismo sucede con la anchura I84 $\mathrm{mm}\left(\mathrm{S}_{\mathrm{I}}\right)$ y I80 $\mathrm{mm}\left(\mathrm{S}_{2}\right)$ y con un intercolumnio entre 20 ( $\mathrm{S}_{\text {I }}$ y $\mathrm{S}_{2}$ ) y $22 \mathrm{~mm}\left(\mathrm{~S}_{2}\right)$. El número de líneas por columna apenas varía, 47 ( $\left.\mathrm{S}_{\text {I y }} \mathrm{S}_{2}\right)$ y 48 ( $\left.\mathrm{S}_{\mathrm{I}}\right)$. Las proporciones de la caja de escritura (I,448 $\mathrm{S}_{\text {I y I, } 45} \mathrm{~S}_{2}$ ) se corresponen a cocientes situados entre el rectángulo de la fórmula a $\mathrm{x}$ a $\sqrt{2}$ y el doble rectángulo de Pitágoras. ${ }^{13}$

La distribución del texto y la caja de escritura de estos fragmentos es muy semejante de la de Cór, y difiere ligeramente de la de $\mathrm{E}_{3}$, como puede verse en el cuadro siguiente:

\begin{tabular}{|c|c|c|c|c|}
\hline & $\mathrm{S}_{\mathrm{I}}$ & $\mathrm{S}_{2}$ & Cór & $\mathrm{E}_{3^{1}}$ \\
\hline Bifolio conservado & central de un cuaderno & exterior de un cuaderno & exterior de un cuaderno & \\
\hline Disposición pergamino & CPPC & PCCP & PCCP & \\
\hline Dimensiones del folio & 314/319 x 218 mm aprox. & $26 \mathrm{I}$ x $258 \mathrm{~mm}$ aprox. & 394 x $25^{8} \mathrm{~mm}$ aprox. & $399 \times 276 \mathrm{~mm}$ \\
\hline Caja de escritura & $267 / 265 \times$ I84 mm & $26 \mathrm{I} \times 180 \mathrm{~mm}$ & $262 / 260 \times$ I $67 / 175 \mathrm{~mm}$ & $216 \times 185 \mathrm{~mm}$ \\
\hline Columna & $8 \mathrm{o} / 8_{4} \mathrm{~mm}$ & $80 \mathrm{~mm}$ & $74 / 79 \mathrm{~mm}$ & 8I mm \\
\hline Intercolumnio & $20 \mathrm{~mm}$ & $2 \mathrm{O} / 22 \mathrm{~mm}$ & I $6 \mathrm{~mm}$ & $23 \mathrm{~mm}$ \\
\hline Núm. líneas escritas & $47 / 48$ & 47 & $47 / 48$ & varía a lo largo del ms. \\
\hline Uso de la primera pauta & $\begin{array}{l}\text { la escritura se dispone } \\
\text { debajo de la primera línea } \\
\text { de pauta }\end{array}$ & $\begin{array}{l}\text { la escritura se dispone } \\
\text { debajo de la primera línea } \\
\text { de pauta }\end{array}$ & $\begin{array}{l}\text { la escritura se dispone } \\
\text { debajo de la primera línea } \\
\text { de pauta }\end{array}$ & $\begin{array}{l}\text { la escritura se dispone } \\
\text { debajo de la primera línea } \\
\text { de pauta }\end{array}$ \\
\hline Proporción & $\begin{array}{l}\text { I, } 448 \text { (entre el rectángulo } \\
\text { de la fórmula a } x \text { a } \sqrt{2} \text { y } \\
\text { el doble rectángulo de } \\
\text { Pitágoras) }\end{array}$ & $\begin{array}{l}\text { I, } 45 \text { (entre el rectángulo } \\
\text { de la fórmula a } x \text { a } \sqrt{2} \text { y } \\
\text { el doble rectángulo de } \\
\text { Pitágoras) }\end{array}$ & $\begin{array}{l}\text { I, } 484 \text {-I, } 568 \text { (doble } \\
\text { rectángulo de Pitágoras) }\end{array}$ & $\begin{array}{l}\text { I, } 4 \text { I (rectángulo de la } \\
\text { fórmula a } x \text { a } \sqrt{2} \text { ) }\end{array}$ \\
\hline
\end{tabular}

I3. Es habitual encontrar diferencias de pocos milímetros en las dimensiones de las cajas a lo largo de un volumen, como puede verse en las tablas de proporciones en manuscritos bíblicos reproducidas en Avenoza (2OII: 3O7-42O). 
4.I.2 Cór: Bifolio de un manuscrito distinto del que proceden $\mathrm{S}_{1}$ y $\mathrm{S}_{2}$

Como puede verse, los fragmentos de la Sisla $\left(\mathrm{S}_{\mathrm{I}}\right.$ y $\left.\mathrm{S}_{2}\right)$ y Cór son muy semejantes. Comparten particulares en la decoración, en la forma y tamaño de rúbricas e iniciales y en la presencia de titulillos (en Si y Cór), además de estar copiados por manos muy próximas en sus usos gráficos (compárense las formas de las "E", "g", "R" por poner algunos ejemplos), que se separan de las propias de $\mathrm{E}_{3}$.

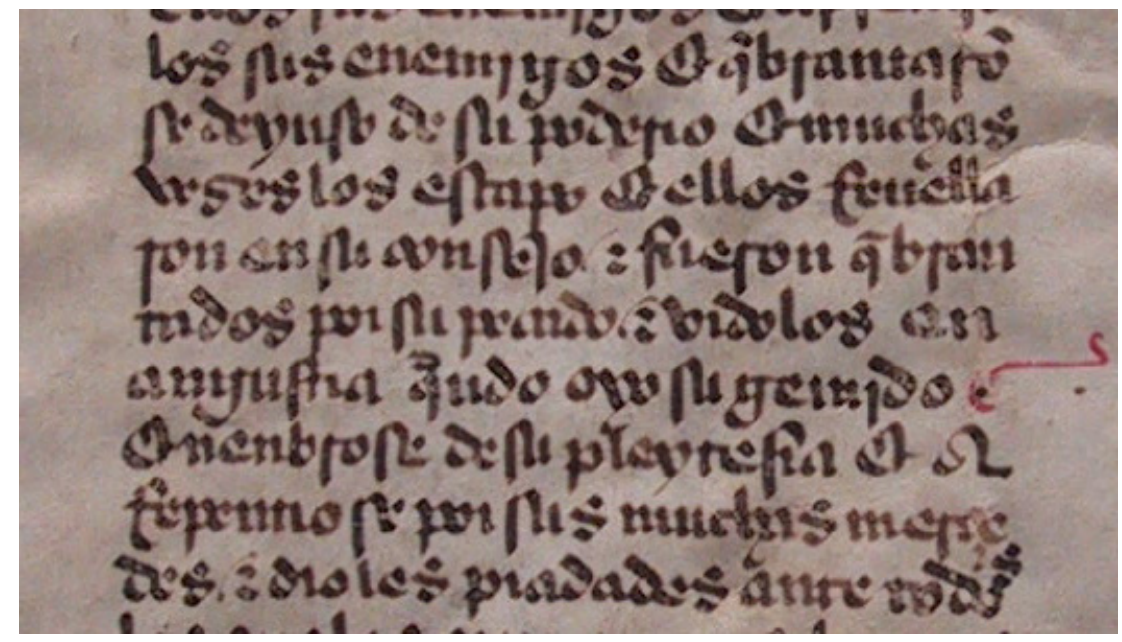

Imagen I4: Córdoba, Archivo de la Catedral Ms. I67 f. [cccxxviij] ${ }^{\text {ra }}$ detalle

(C) Catedral de Córdoba

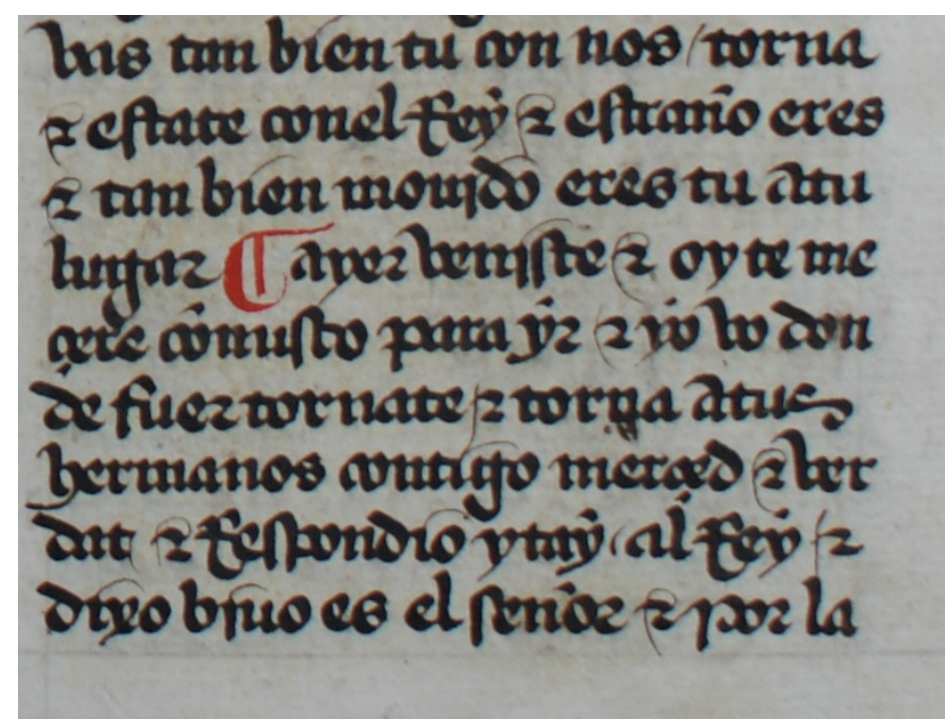

Imagen I5: Esc I-I-3 f. clxxxij" detalle

(C) Real Biblioteca del Monasterio de El Escorial 
Las semejanzas entre SI, S2 y Cór hicieron pensar que estos tres fragmentos podían proceder de un mismo manuscrito, pero la distribución de los textos copiados en $\mathrm{S}_{2}$ y Cór lo hace imposible:

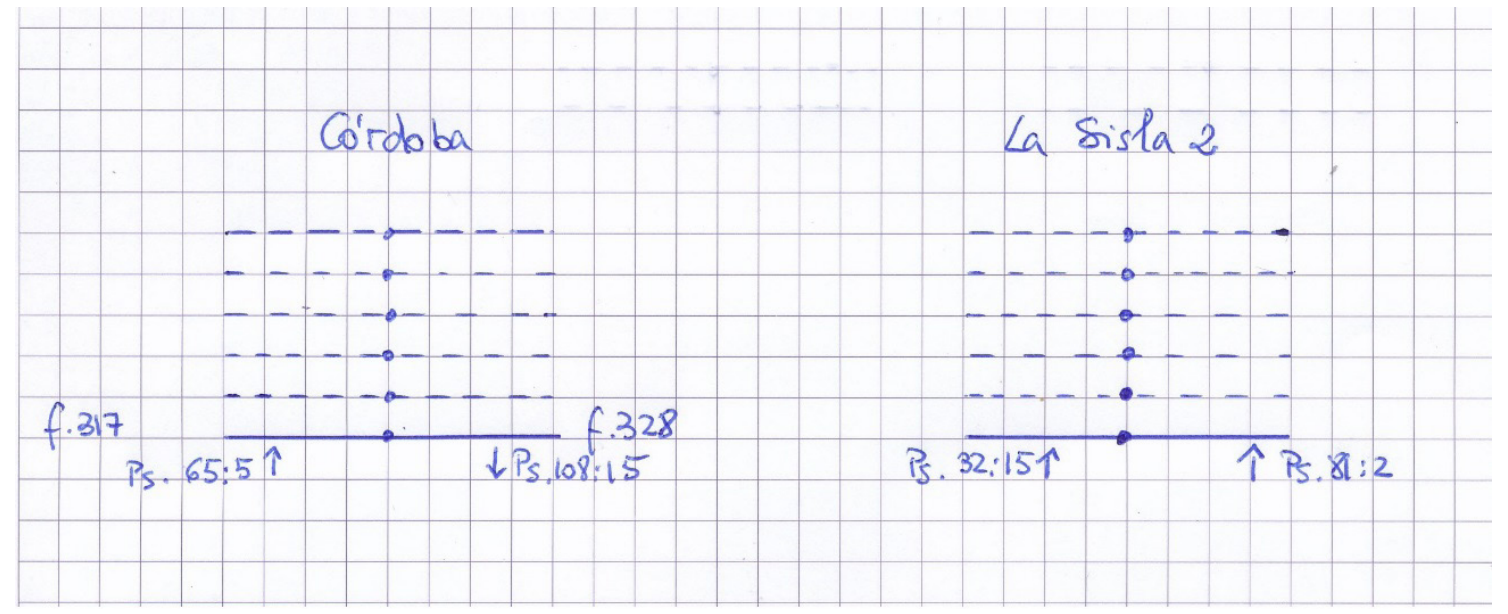

Imagen i6: contenido textual de los cuadernos de Cór y $\mathrm{S}_{2}$

Aunque se tratara de manuscritos copiados íntegramente sobre pergamino, al ser el bifolio de Córdoba el pliego exterior de un cuaderno (Sal. 65·5-Io8.I5), es imposible que S2 (Sal. 32.I5-8I.2) perteneciera al mismo cuaderno, por lo que se trata de restos de códices distintos, aunque muy semejantes en su factura y probablemente contemporáneos.

5 Relaciones textuales entre $S_{\text {I }}$ (Ezequiel I6.25-I8.30), S2 (Salmos 32.II-36.7 y 78.25-8I.2), Cór (Salmos 55.6-68.35y Io6.36-Io8.I2) y E $3_{\mathbf{r}}$ (Biblia completa)

$\mathrm{H}_{\mathrm{a}}$ asta este momento contamos con dos testimonios manuscritos de la traducción copiada en E3 $3_{\mathrm{I}}$ para los textos de Ezequiel, y tres para el de Salmos: el códice escurialense y restos de otros dos códices: Cór, Si y S2, y los dos fragmentos de la Sisla (frags. Ezequiel y Salmos), procedentes de sendas biblias desmembradas, como lo demuestran los restos de las foliaciones conservadas, correspondientes a volúmenes de generosas dimensiones.

Ya se ha tratado la identidad de los textos de SI, Cór y E $3_{\text {I }}$ (Avenoza 2OII: 3I9-2O y Avenoza 20I7). Los ejemplos que aquí se aportan de $\mathrm{S}_{2}$ demuestran que también traduce el texto de $\mathrm{E}_{3}$. Dado que el proceso de copia está inevitablemente sujeto al error humano, existen divergencias entre $\mathrm{S}_{2}$ y $\mathrm{E}_{3}$; algunas de poco calado, pero otras que nos permiten avanzar en la comprensión de las relaciones entre ambos testimonios.

\section{I Cór, $S_{1}, S_{2}$ y $E_{3,}$ : una misma traducción}

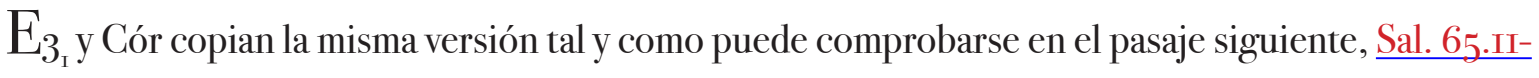




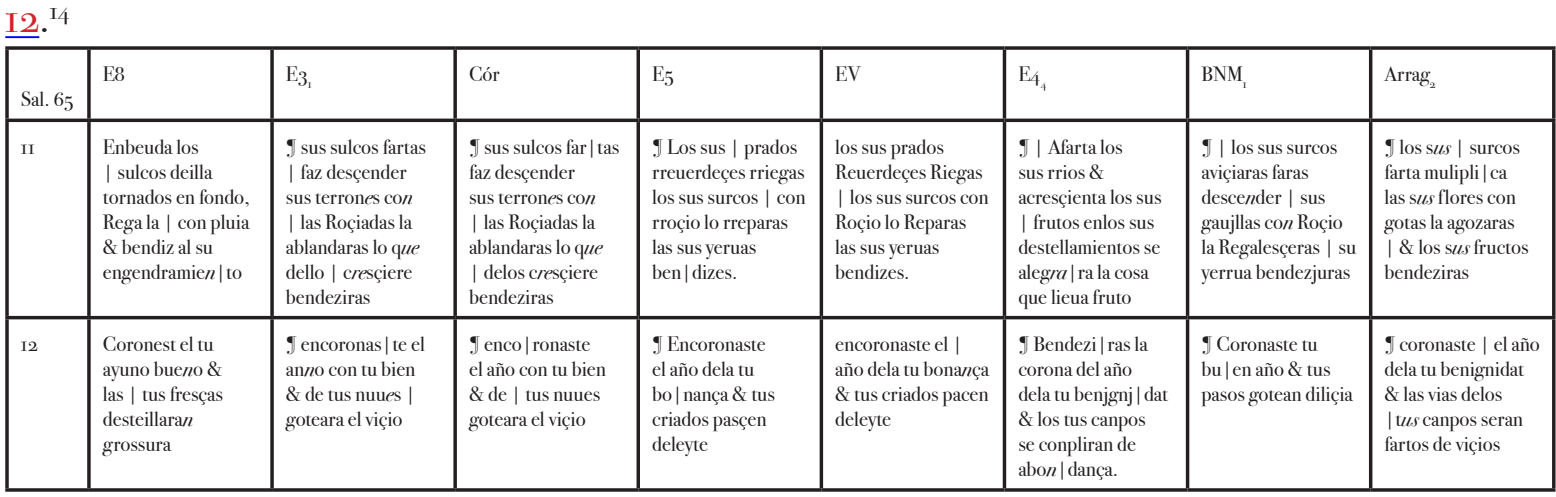

$\mathrm{E}_{3}$ y $\mathrm{S}_{2}$, por su parte, coinciden en pasajes en los que el texto presenta soluciones distintas de las que transmite el resto de las traducciones castellanas conservadas. Como ejemplo, en las lecturas de los cuatro primeros versículos del $\underline{\text { Sal. } 35 . \mathrm{I}-4} \cdot{ }^{{ }^{15}}$

\begin{tabular}{|c|c|c|c|c|c|c|c|c|}
\hline Sal. & E8 & $\mathrm{E}_{3_{1}}$ & $\mathrm{~S}_{2}$ & $\mathrm{E}_{5}$ & EV & $\mathrm{E}_{4_{4}}$ & $\mathrm{BNM}_{t}$ & $\operatorname{Arrag}_{2}$ \\
\hline & $\begin{array}{l}\text { palmus. Judicame } \\
\text { domine nocentes } \\
\text { me. I }\end{array}$ & $\begin{array}{l}\text { [f. } 395^{\mathrm{vb}} \text { ] } \text { capitulo } \\
\text {.xxxv. adaujd | }\end{array}$ & $\begin{array}{l}\mathbb{I}\left[{ }^{* *}\right] \text { capitolo } \\
\text { xxxv. adaujd | }\end{array}$ & $\begin{array}{l}\text { A daujd quan | do se } \\
\text { mudo su aluedrio } \\
\text { ante abimeleque } \\
\& \text { de | terrolo \& } \\
\text { fuesse. xxxiiij. [f. } \\
\text { I38vb] }\end{array}$ & [psalmo a daujt] | & & $\begin{array}{l}\text { Adaujd psalmo } \\
\text { treynta \& seys | }\end{array}$ & $\begin{array}{l}\text { xxxiiij | I judica } \\
\text { domjne nocentes } \\
\text { me. | }\end{array}$ \\
\hline I & $\begin{array}{l}\text { Contiende Sennor } \\
\text { con los mios } \\
\text { auerssa| rios, lidia } \\
\text { contra los que ami } \\
\text { conbaten | }\end{array}$ & $\begin{array}{l}\text { Pelea sennor con } \\
\text { los que pelean | } \\
\text { comjgo guerra con } \\
\text { los que | guerrean } \\
\text { comjgo }\end{array}$ & $\begin{array}{l}\mathrm{P}(4)[* * *] \\
\text { sennor con los } \\
\text { que pele } \mid\left[{ }^{* *}\right]\left[{ }^{*}\right] \\
\text { omjgo guerrea con } \\
\mid \text { los que guerrean } \\
\text { comj|go guerrea } \\
\text { con los que } \mid \\
\text { guerrean comjgo }\end{array}$ & $\begin{array}{l}\text { Baraje el } \\
\text { señor alos mjs } \\
\text { conquista| dores } \\
\text { pelee alos mjs } \\
\text { peleadores }\end{array}$ & $\begin{array}{l}\text { Baraje el señor alos } \\
\text { mjs conquistadores } \\
\text { pelee alos mjs } \\
\text { peleadores. }\end{array}$ & $\begin{array}{l}\text { Iudga señor alos } \\
\text { que me enpes | çen } \\
\text { \& lidia todos los } \\
\text { que me | lidian. }\end{array}$ & $\begin{array}{l}\text { [P]leytea señor mjs } \\
\text { ple|ytos batalla } \\
\text { | contra mjs } \\
\text { batalladores }\end{array}$ & $\begin{array}{l}\text { Judga señor los que } \\
\text { comigo pelean [me } \\
\text { nuzen] f. } 402 \text { ra] \& } \\
\text { batalla tu las mis } \\
\text { batallas }\end{array}$ \\
\hline 2 & $\begin{array}{l}\text { Toma armas escudo } \\
\& \text { lança | leuanta te } \\
\text { en mi ayuda. }\end{array}$ & $\begin{array}{l}\text { I tra | ua de } \\
\text { manpara \& adaraga } \\
\text { | \& leuantate en mj } \\
\text { ayuda }\end{array}$ & $\begin{array}{l}\text { I traua de } \\
\text { man | para \& lança } \\
\& \text { le | uanta te en la } \\
\text { mj ayuda }\end{array}$ & $\begin{array}{l}\text { I Enforteçe escudo } \\
\text { \& lança \& le | uanta } \\
\text { te en la mj ayuda }\end{array}$ & $\begin{array}{l}\text { S en | fortesçe a } \\
\text { escudo \& lança \& } \\
\text { leuantate enla mj } \\
\text { ayuda }\end{array}$ & $\begin{array}{l}\text { I Toma armas } \\
\text { \& es | cudo \& } \\
\text { leuantate en mi } \\
\text { ayuda | }\end{array}$ & $\begin{array}{l}\text { I tra | ua del escudo } \\
\& \text { del adaraga \& } \\
\text { leuantate | en mj } \\
\text { ayuda }\end{array}$ & $\begin{array}{l}\text { I toma ar } \mid \text { mas \& } \\
\text { escudo \& leuantate } \\
\text { ame ayudar }\end{array}$ \\
\hline 3 & $\begin{array}{l}\text { Saca el espa| da \& } \\
\text { para te esquantra } \\
\text { los que ami siguen, } \\
\text { di | tu ala mi } \\
\text { alma, yo so tu } \\
\text { defendimiento | }\end{array}$ & $\begin{array}{l}\text { I \& saca | lança\& } \\
\text { çierra al encuentro } \\
\text { delos que | me } \\
\text { siguen dy | por mj } \\
\text { anjma tu saluaçi| on } \\
\text { so yo }\end{array}$ & $\begin{array}{l}\text { \& saca lança \& } \\
\text { cierra al en | cuentro } \\
\text { delos que me siguen } \\
\text { dy | por mj mj } \\
\text { anjma tu saluaçion }\end{array}$ & $\begin{array}{l}\text { I Aguza el } \\
\text { ar| ma \& çierra al } \\
\text { encuentro delos } \\
\text { mjs perseguj | dores } \\
\text { di ala mj alma la tu } \\
\text { saluaçion so yo. | }\end{array}$ & $\begin{array}{l}\text { S aguza el ar | ma } \\
\text { \& çierra al } \\
\text { encuentro delos } \\
\text { mjs segujdores dy } \\
\text { al amj alma la tu } \\
\text { salua| çion so yo. }\end{array}$ & $\begin{array}{l}\text { I Desuayna la } \\
\text { espada \& aparejate } \\
\text { con } \mid \text { tra los que me } \\
\text { persiguen \& di ala } \\
\text { mi | alma tu salud } \\
\text { so yo. }\end{array}$ & $\begin{array}{l}\text { IE Remesa la lança } \\
\& \text { blan } \mid \text { dela al } \\
\text { encuentro de mjs } \\
\text { siguientes di a|mj } \\
\text { alma tu saluaçion } \\
\text { so yo }\end{array}$ & $\begin{array}{l}\text { I I I \& toma la } \\
\text { lança [ \& esparze tu } \\
\text { la espada tornabjle] } \\
\text { \& ençierra \& sigue } \\
\text { los que | me siguen } \\
\text { dy tu ala mi anima } \\
\text { tu saluaçion | y }\end{array}$ \\
\hline 4 & $\begin{array}{l}\text { Fallezcan \& sean } \\
\text { enuergonçados, } \\
\text { lo que de | mandan } \\
\text { la mi alma, tornen } \\
\text { atras \& sean } \\
\text { co| fondidos los que } \\
\text { pienssan mal pora } \\
\mathrm{mi} / . \text { | }\end{array}$ & $\begin{array}{l}\text { I auergonçarsean } \\
\text { \& vitu| periarsean } \\
\text { los que buscan } \\
\text { mj anjma | } \\
\text { tornaran atras \& } \\
\text { vituperiarssean } \\
\mid \text { los que piensan } \\
\text { contra mj mal }\end{array}$ & $\begin{array}{l}\text { I a | uergonçarsean } \\
\& \text { bituPeriarsean } \mid \\
\text { los que buscan mj } \\
\text { Anjma torna| ran } \\
\text { atras \& vitupiarsean } \\
\text { los que | Piensan } \\
\text { contra mj mal }\end{array}$ & $\begin{array}{l}\text { I Sean } \\
\text { envergonçados } \\
\text { \& vituperados } \\
\text { aque |llos que } \\
\text { buscan la mj alma. } \\
\text { acaguen atras \& } \\
\text { | sean rretraydos } \\
\text { los que piensan del } \\
\text { mj mal. }\end{array}$ & $\begin{array}{l}\text { sean envergonçados } \\
\& \text { vituperiados } \\
\text { aquellos que buscan } \\
\text { la my [f. } 354 \mathrm{r}] \text { alma } \\
\text { açaguen atras \& } \\
\text { sean Retraydos los } \\
\text { que piensan del } \\
\text { mj mal. }\end{array}$ & $\begin{array}{l}\text { 9 Confondidos } \\
\text { | sean \& } \\
\text { enverguençen los } \\
\text { que demandan } \\
\text { | la mi alma. \$ } \\
\text { Confondidos sean } \\
\text { \& | torrnados atras } \\
\text { los que me pienssan } \\
\text { | mal. }\end{array}$ & $\begin{array}{l}\text { S enverguen } \mid \text { çense } \\
\& \text { turben se los } \\
\text { demandadores } \\
\text { de | mj alma } \\
\text { Retraygan se atras } \\
\text { \& enverguen } \mid \text { çense } \\
\text { los que piensan } \\
\text { mj mal }\end{array}$ & $\begin{array}{l}\text { I confundidos \& } \\
\text { auergoncados sean } \\
\text { | los que en mal } \\
\text { busan la mi anima } \\
\text { retroga | dos sean a } \\
\text { çaga \& confundidos }\end{array}$ \\
\hline
\end{tabular}

Dentro de este salmo, el segundo versículo permite contrastar las distintas opciones traductológicas:

E8: Toma armas escudo \& lança | \& leuanta te en mi ayuda.

GE: prende arma e escudo, e levantate en ayuda a mi.

S2: I traua de man | para \& adaraga \& leuantate e $n$ mj | ayuda

I4. Los textos de las tablas siguientes proceden de la base de datos Bibliamedieval.es (http://corpus.bibliamedieval. es).

I5. A los textos de Bibliamedieval.es se han añadido los textos correspondientes de S2, que aún no están integrados en ese corpus. 
E3: I tra| ua de manpara \& adaraga | \& leuantate en mj ayuda

E5: I Enforteçe escudo \& lança \& le | uanta te en la mj ayuda.

EV: I en | fortesçe a escudo \& lança \& leuantate enla mj ayuda

$\mathrm{E}_{4}$ : I Toma armas \& es | cudo \& leuantate en mi ayuda |

$\mathrm{BNM}_{\mathrm{I}}$ : I tra| ua del escudo \& del adaraga \& leuantate | en mj ayuda

$\operatorname{Arrag}_{2}$ : I toma ar $\mid$ mas \& escudo \& leuantate ame ayuda.

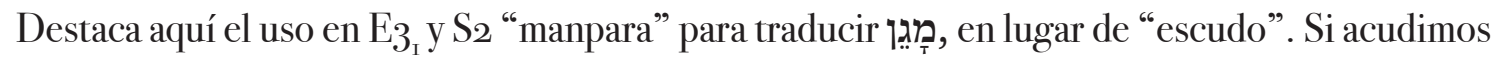
a Bibliamedieval.es, es evidente que $\mathrm{E}_{3_{\mathrm{I}}}$ es, de todas las traducciones, la que traduce de forma más sistemática מָָָ por "manpara” (cuando se trata de un sustantivo) donde los demás suelen emplear "escudo". ${ }^{16}$

Otro ejemplo en el que la traducción transmitida por $\mathrm{E}_{3}$ y $\mathrm{S}_{2}$ se aparta notablemente del resto se halla en 33.IO:

[33.Io] el señor priuo $\mathrm{S}_{2}$ ] el señor priua E3 3 ; Dios desata E8; el señor dios desconçierta E5; el señor desconçierta EV; Dios desfaze $\mathrm{E}_{4}$; el señor derramo BNM${ }_{1}$; el señor quebranta Arrag ${ }_{2}$; Dominus dissipat consilia gentium reprobat autem cogitationes populorum et reprobat consilia principum

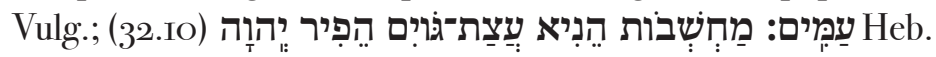

$\mathrm{E}_{3_{\mathrm{I}}} \mathrm{y} \mathrm{S}_{2}$ coinciden en la elección del verbo, aunque discrepan en el tiempo verbal (BNM $\mathrm{I}_{\mathrm{I}}$ es la única traducción que emplea una forma de pasado en este versículo). ${ }^{17}$

Existen otros ejemplos en los que la traducción copiada en $\mathrm{E}_{3_{\mathrm{I}}}$ y $\mathrm{S}_{2}$ presenta soluciones divergentes frente a las demás. Por ejemplo, el uso de "corneta" en Sal. 33.3, que es vocablo exclusivo de esta traducción (I 4 versículos documenta Bibliamedieval.es en todo el texto). Según Pueyo Mena (en preparación), cuerno y su diminutivo corneta son los dos únicos términos que

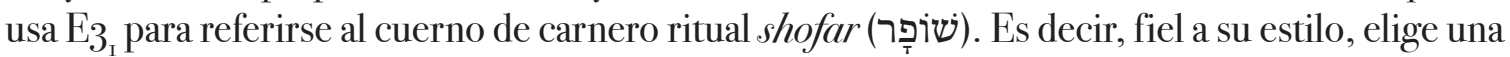
raíz castellana y literal (el shofar es literalmente un cuerno de carnero), frente a las opciones que prefieren el resto de traducciones (bozina, trompeta, etc.).

\begin{tabular}{|c|c|c|c|c|c|c|c|c|c|c|c|}
\hline Fazienda & E8 & GE & $\mathrm{E}_{3_{1}}$ & $\mathrm{~S}_{2}$ & $\mathrm{E}_{5}$ & EV & $\mathrm{E}_{4_{4}}$ & $\mathrm{BNM}_{\mathrm{t}}$ & $\operatorname{Arrag}_{2}$ & Latín & Hebreo \\
\hline $\begin{array}{l}\text { Cantat } \\
\text { le nueuo } \\
\text { contar et } \\
\text { alabat le bien } \\
\text { agrandes } \\
\text { uozes et | } \\
\text { muchas. | }\end{array}$ & $\begin{array}{l}\text { Cantad adios } \\
\text { cantigo } \\
\text { nueuo \& loat } \\
\text { lo | bien en } \\
\text { cantando. }\end{array}$ & $\begin{array}{l}\text { Cantatle } \\
\text { cantico } \\
\text { nuevo; } \\
\text { cantatle bien } \\
\text { a grandes } \\
\text { bozes. }\end{array}$ & $\begin{array}{l}\text { I cantad } \\
\text { al sennor } \\
\text { can } \mid \text { to } \\
\text { nueuo } \\
\text { adresçad de } \\
\text { tanner con } \\
\text { cor } \mid \text { neta }\end{array}$ & $\begin{array}{l}\left.\mathrm{ca}{ }^{* * *}\right] \text { al } \\
\text { sennor canto } \\
\text { I nueuo } \\
\text { adreçad d }\left[{ }^{*}\right] \\
{\left[{ }^{* *}\right] \text { nner }} \\
\text { con corneta }\end{array}$ & $\begin{array}{l}\text { cantad ael } \\
\text { cantj| tco } \\
\text { nueuo. \& } \\
\text { tenplat el } \\
\text { muedo del } \\
\text { tenor. }\end{array}$ & $\begin{array}{l}\text { Cantad ael } \\
\text { cantico. } \\
\text { Nueuo. \& } \\
\text { tenplad el } \\
\text { muedo del } \\
\text { tenor }\end{array}$ & $\begin{array}{l}\text { g Cantadle } \\
\text { cantar } \\
\text { nueuo \& } \\
\text { bien le | t } \\
\text { candad ael } \\
\text { en boz }\end{array}$ & $\begin{array}{l}\text { I cantad [f. } \\
\text { I2gvb] al } \\
\text { señor cantar } \\
\text { nueuo tañed } \\
\text { bien con } \mid \mathrm{t} \\
\text { estruendo }\end{array}$ & $\begin{array}{l}\text { I cantad } \\
\text { ael cantico } \\
\mid \mathrm{t} \text { nueuo } \\
\text { fazed buen } \\
\text { cantar con } \\
\text { jubilaçion | }\end{array}$ & $\begin{array}{l}32.3] \text { cantante } \\
\text { ei canticum } \\
\text { novum bene } \\
\text { psallite in } \\
\text { vociferatione }\end{array}$ & 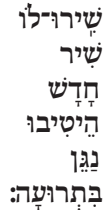 \\
\hline
\end{tabular}

Llama también la atención del uso de la paráfrasis "razones de arte” para la idea de "engaño", como sucede en Sal. 35.20 y en 36.4 (maldad \& arte), frente a las soluciones de las demás traducciones ("palabras engañosas" E8; "engaños" GE; "palabras traydoras" E5/EV; "palabras de engaño" BNM; “palabras dolosas” Arrag.). El uso de "razones” para "palabras” y "arte” para "engaño" está registrado en español medieval, pero en el corpus Bibliamedieval.es, el traductor de

I6. Debo a F. Javier Pueyo Mena las precisiones relativas a los textos hebreos a las que aludiré, y le agradezco que haya compartido conmigo materiales de un trabajo que actualmente está en curso de elaboración y al que me refiero en la bibliografía con un título provisional.

I7. Hay que tener en cuenta que en este punto $\mathrm{S}_{2}$ presenta dificultades de lectura por su estado de conservación. 
E $3_{\text {I }}$ es el único que emplea de forma consistente "arte" para el concepto de "engaño" (34 frente a 3 ocurrencias), mientras que el resto de traducciones sólo lo hace de forma puntual.

\begin{tabular}{|c|c|c|c|c|c|c|c|c|c|c|}
\hline E8 & GE & $\mathrm{E}_{3_{\mathrm{t}}}$ & $\mathrm{S}_{2}$ & $\mathrm{E}_{5}$ & $\mathrm{EV}$ & $\mathrm{E}_{4_{4}}$ & $\mathrm{BNM}_{1}$ & $\operatorname{Arrag}_{2}$ & Latín & Hebreo \\
\hline $\begin{array}{l}\text { Car no fablan } \\
\text { paz | mas } \\
\text { pienssan } \\
\text { palauras } \\
\text { engannosas } \\
\text { en ti } \mid \text { empos } \\
\text { de momento/: }\end{array}$ & $\begin{array}{l}\text { Ca me } \\
\text { fablavan } \\
\text { en paz; e } \\
\text { fablandome } \\
\text { en saña de } \\
\text { la tierra } \\
\text { asmavanme } \\
\text { engaños. }\end{array}$ & $\begin{array}{l}\text { I que non } \\
\text { fablan en paz } \\
\& \text { con } \mid \text { los } \\
\text { viçiosos dela } \\
\text { tierra rrazones } \\
\text { de | artes } \\
\text { piensan }\end{array}$ & $\begin{array}{l}\text { Sque non } \\
\text { fablan en paz } \\
\& \text { conlos I } \\
\text { viçiosos dela } \\
\text { tierra Razones } \\
\& \text { arte | } \\
\text { Piensan }\end{array}$ & $\begin{array}{l}\text { I Ca nunca } \\
\text { paz fablan } \\
\& \text { sobre los } \\
\text { gran } \mid \text { des } \\
\text { [f. I } 4 \text { ora] } \\
\text { dela tierra } \\
\text { \$ Palabras } \\
\text { traydoras } \\
\text { pien| san }\end{array}$ & $\begin{array}{l}\text { 9 Ca nunca } \\
\text { paz fablan I } \\
\text { \& sobre los } \\
\text { gandes dela } \\
\text { tierra palabras } \\
\text { traydoras } \\
\text { piensan. }\end{array}$ & $\begin{array}{l}\text { g Ca con paz } \\
\text { me fablauan } \\
\text { \& | en saña } \\
\text { dela tierra } \\
\text { \& quando } \\
\text { fablauan } \\
\text { engaños } \\
\text { cuydauan. }\end{array}$ & $\begin{array}{l}\text { I Ca non en } \\
\text { paz | fablan } \\
\text { \& sobre los } \\
\text { Resquebrajos } \\
\text { de | la tierra } \\
\text { palabraws } \\
\text { de engaño } \\
\text { piensan | }\end{array}$ & $\begin{array}{l}\text { I que non } \\
\text { fablan | pax } \\
\text { \& fablandome } \\
\text { [en] saña } \\
\text { de[la] tierra } \\
\text { palabras } \\
\text { do|losas } \\
\text { fablan } \\
\text { [piensan] }\end{array}$ & $\begin{array}{l}(34 \cdot 20) \\
\text { quoniam } \\
\text { mihi quidem } \\
\text { pacifice } \\
\text { loquebantur } \\
\text { et in iracundia } \\
\text { terrae } \\
\text { loquentes } \\
\text { doos } \\
\text { cogitabant }\end{array}$ & 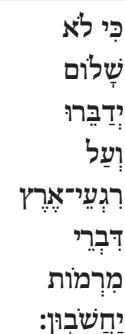 \\
\hline
\end{tabular}

En Sal. 78.45 E 3 $_{\text {I }} \mathrm{S}_{2}$ optan por "mestura" donde las demás traducciones emplean "moscas", "boltura", "vestiglos", "mezclas de animalias" o "çinonaam [moscas]". No se ha encontrado en los corpora de la RAE ninguna ocurrencia de "mestura" con este significado fuera de los ejemplos bíblicos y, de hecho, solamente aparece en $\mathrm{E}_{3}$, $\mathrm{S}_{2}$ y en algún pasaje de Er9 (Éx. 8.I7, 8.I8, 8.2O, 8.25, 8.27; Sal. IO5.3г bajo las formas mistura, mystura o mestura), de Arragel solo en Éx., en Sal. mantiene el latín "cynomiam", aunque en el interlineado añade “moscas"). Según Pueyo Mena (en preparación) la forma "mestura" traduce literalmente "arob" (עָרב ) "mezcla", forma de significado oscuro y que aparece en siete ocasiones en la Biblia. Literalmente no significa "insectos o animales" sino "mezcla, mixtura", y se entendería como "plaga de animales mezclados e indeterminados".

\begin{tabular}{|c|c|c|c|c|c|c|c|c|c|}
\hline GE & $\mathrm{E}_{3_{i}}$ & $\mathrm{~S}_{2}$ & $E_{5}$ & EV & $\mathrm{E}_{4_{4}}$ & $\mathrm{BNM}_{1}$ & $\mathrm{Arrag}_{2}$ & Latín & Hebreo \\
\hline $\begin{array}{l}\text { envio sobrellos } \\
\text { moscas que les } \\
\text { comio, e ranas; } \\
\text { e esparziolos. }\end{array}$ & $\begin{array}{l}\text { I soltaua } \\
\text { ene | llos } \\
\text { mestura \& } \\
\text { comjalos \& } \\
\text { rranas | \& } \\
\text { dannaualos }\end{array}$ & $\begin{array}{l}\text { I solaua enellos } \\
\text { mestura | } \\
\text { \& comjalos } \\
\text { \& Ranas \& } \\
\text { dannaualos }\end{array}$ & $\begin{array}{l}\text { I E enbio } \\
\text { ene | |los boltura } \\
\text { \& estragolos \& } \\
\text { rranas quelos } \\
\text { dañaron }\end{array}$ & $\begin{array}{l}\text { SE enbio } \\
\text { enellos boltura } \\
\text { \& estragolos \& } \\
\text { Ranas que |los } \\
\text { dapñaron. }\end{array}$ & $\begin{array}{l}\text { Enbio contra } \\
\text { ellos ves| tiglos } \\
\text { quelos } \\
\text { comjesen \& } \\
\text { rranas \& | } \\
\text { esparziolos }\end{array}$ & $\begin{array}{l}\text { I Enbio enellos } \\
\text { mezclas | de } \\
\text { anjmaljas \& } \\
\text { comjeron los } \\
\text { \& Ranas \& | } \\
\text { dañaron los }\end{array}$ & $\begin{array}{l}\text { enbio enelos } \\
\text { ínonaam } \\
\text { [moscas] \& } \\
\text { comio los \& } \\
\text { ra| nas que los } \\
\text { distruyeron }\end{array}$ & $\begin{array}{l}\text { (77.45) misit in } \\
\text { eos cynomiam } \\
\text { et comedit eos } \\
\text { et ranam et } \\
\text { disperdit eos }\end{array}$ & 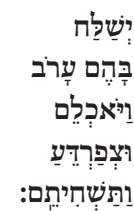 \\
\hline
\end{tabular}

\subsection{Relaciones entre $E_{3}, y S_{2}$}

$$
\text { 5.2.I } \mathrm{S}_{2} \text { no copia } \mathrm{E}_{3_{\text {I }}}
$$

$$
\text { 5.2.I.I Lagunas }
$$

La Sisla 2 no es una copia de $\mathrm{E}_{3}$, dado que existen lagunas en $\mathrm{E}_{3_{\mathrm{I}}}$ que completa $\mathrm{S}_{2}$.

[33.7 ] el | que Apaña commo vn monton las | aguas dela mar] Commo vn monton las aguas dela $\operatorname{mar} \mathrm{E}_{3_{1}}$. 


\begin{tabular}{|c|c|c|c|c|c|c|c|c|c|c|c|}
\hline $\begin{array}{l}\text { Sal. } \\
33\end{array}$ & E8 & GE & $\mathrm{E}_{3_{1}}$ & $\mathrm{~S}_{2}$ & $\mathrm{E}_{5}$ & $\mathrm{EV}$ & $\mathrm{E}_{4_{4}}$ & $\mathrm{BNM}_{\mathrm{t}}$ & $\operatorname{Arrag}_{2}$ & Latín & Hebreo \\
\hline 6 & $\begin{array}{l}\text { Por el } \\
\text { vierbo de } \\
\text { | dios son } \\
\text { affirmados } \\
\text { los Cielos, y } \\
\text { enel spiritu } \\
\text { | de su } \\
\text { boca es toda } \\
\text { la virtut } \\
\text { deillos. }\end{array}$ & $\begin{array}{l}\text { Por la paavra } \\
\text { del Señor son } \\
\text { firmados los } \\
\text { cielos e por } \\
\text { el espiritu } \\
\text { de la su boca } \\
\text { toda la virtud } \\
\text { dellos; }\end{array}$ & $\begin{array}{l}\text { por la } \\
\text { palabr } a \mid \\
\text { del sennor } \\
\text { los çielos } \\
\text { se fezieron } \\
\text { \& por | el } \\
\text { espirito de } \\
\text { su boca toda } \\
\text { su conpanna }\end{array}$ & $\begin{array}{l}\text { I por la } \\
\text { palabra del } \\
\text { | sennor } \\
\text { los çielos } \\
\text { se fizieron } \\
\text { \& por el } \\
\text { espi| rito } \\
\text { de su boca } \\
\text { toda su } \\
\text { conpanna }\end{array}$ & $\begin{array}{l}\text { S Conla } \\
\text { palabra del } \\
\text { señor | los } \\
\text { çielos se } \\
\text { fizjeron \& } \\
\text { conel [e] } \\
\text { spiritu dela } \\
\text { su boca las } \\
\text { sus cortes. }\end{array}$ & $\begin{array}{l}\text { I conla } \\
\text { palabra del } \\
\text { | señor } \\
\text { los çielos } \\
\text { se fizieron } \\
\text { \& conel } \\
\text { espirito dela } \\
\text { su boca las } \\
\text { sus cortes. }\end{array}$ & $\begin{array}{l}\text { Por la } \\
\text { palabra de } \\
\text { dios son } \\
\text { fechos los } \\
\text { | çielos } \\
\text { \& por el } \\
\text { spiritu dela } \\
\text { su boca } \\
\text { es toda } \\
\text { | fuerça } \\
\text { dellos. }\end{array}$ & $\begin{array}{l}\text { por la palabra } \\
\text { del | señor } \\
\text { se fizjeron \& } \\
\text { por el espiritu } \\
\text { | desu boca } \\
\text { todas sus } \\
\text { huestes }\end{array}$ & $\begin{array}{l}\text { I por la } \\
\text { palabra del } \\
\text { señor | los } \\
\text { çielos fechos } \\
\text { son \& conl } \\
\text { spirittu dela } \\
\text { su boca | } \\
\text { todos los sus } \\
\text { hornamentos }\end{array}$ & $\begin{array}{l}\text { (32.6) verbo } \\
\text { Domini caeli } \\
\text { firmati sunt } \\
\text { et spiritu oris } \\
\text { eius omnis } \\
\text { virtus eorum }\end{array}$ & 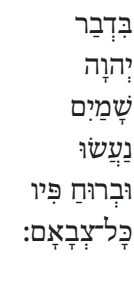 \\
\hline 7 & $\begin{array}{l}\text { Que | } \\
\text { aplega } \\
\text { las aguas } \\
\text { del mar } \\
\text { assi como } \\
\text { mon } \mid \text { ton, } \\
\text { que alça en } \\
\text { thesoro los } \\
\text { dilluuios } \\
\text { de | las } \\
\text { aguas | }\end{array}$ & $\begin{array}{l}\text { que ayunta } \\
\text { como en odre } \\
\text { las abuas de } \\
\text { la mar e pone } \\
\text { los abismos } \\
\text { en tesoros. }\end{array}$ & $\begin{array}{l}\text { Commo vn } \\
\text { monton las } \\
\text { aguas dela } \\
\text { mar el | } \\
\text { que pone en } \\
\text { thesoros los } \\
\text { abismos }\end{array}$ & $\begin{array}{l}\text { I el | que } \\
\text { Apaña } \\
\text { commo vn } \\
\text { monton las } \\
\text { aguas dela } \\
\text { mar / el que } \\
\text { pone en } \\
\text { tesoros | los } \\
\text { abismos }\end{array}$ & $\begin{array}{l}\text { S Allego } \\
\text { como | } \\
\text { en odre } \\
\text { las aguas } \\
\text { del mar. } \\
\text { dio enlos } \\
\text { alle | ros los } \\
\text { abismos. }\end{array}$ & $\begin{array}{l}\text { S allego } \\
\text { como | } \\
\text { en odre } \\
\text { las aguas } \\
\text { del mar.. } \\
\text { dio enlos } \\
\text { çilleros los } \\
\text { abismos }\end{array}$ & $\begin{array}{l}\text { S Allego } \\
\text { asi commo } \\
\text { en | odre } \\
\text { las aguas } \\
\text { dela mar } \\
\text { \& puso los } \\
\text { abis|mos } \\
\text { asi } \\
\text { commo en } \\
\text { thesoro. }\end{array}$ & $\begin{array}{l}\text { I apañan | te } \\
\text { como monton } \\
\text { las aguas } \\
\text { dela mar } \\
\text { po|nientelas } \\
\text { enlos } \\
\text { almazenes } \\
\text { delos | } \\
\text { abismos }\end{array}$ & $\begin{array}{l}\text { I junto commo } \\
\text { | monton } \\
\text { [odre] las } \\
\text { aguas del mar } \\
\text { puso thesoreos } \\
\text { | enlos } \\
\text { abismos }\end{array}$ & $\begin{array}{l}(32.7) \\
\text { congregans } \\
\text { sicut in utre } \\
\text { aquas maris } \\
\text { ponens in } \\
\text { thesauris } \\
\text { abyssos }\end{array}$ & 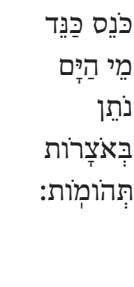 \\
\hline 8 & $\begin{array}{l}\text { Tema } \\
\text { adios toda } \\
\text { la tierra, } \\
\text { aeill ayan } \\
\text { mie| do los } \\
\text { moradores } \\
\text { de todel } \\
\text { Sieglo. }\end{array}$ & $\begin{array}{l}\text { Tema al Señor } \\
\text { toda la tierra } \\
\text { e del sean } \\
\text { conmovidos } \\
\text { todos los que } \\
\text { moran en la } \\
\text { redondeza } \\
\text { della. }\end{array}$ & $\begin{array}{l}\mathbb{I} \text { । } \\
\text { temeran del } \\
\text { sennor todos } \\
\text { los de | la } \\
\text { tierra del se } \\
\text { rreçelaran } \\
\text { todos los } \\
\text { mo| radores } \\
\text { del mundo }\end{array}$ & $\begin{array}{l}\text { I temeran } \\
\text { del sennor } \\
\text { todos | } \\
\text { los dela } \\
\text { tierra del } \\
\text { se Reçelan } \\
\text { todos [***] } \\
\text { | moradores } \\
\text { del mundo }\end{array}$ & $\begin{array}{l}\text { S Temeran } \\
\text { del señor } \\
\text { to | dos } \\
\text { los dela } \\
\text { tierra del se } \\
\text { rresçelaran } \\
\text { todos los | } \\
\text { pobladores } \\
\text { del mundo. }\end{array}$ & $\begin{array}{l}\text { S temeran } \\
\text { del señor } \\
\text { | todos } \\
\text { los dela } \\
\text { tierra delse } \\
\text { Resçelaran } \\
\text { todos los } \\
\text { pobladores } \\
\text { del(a tierra) } \\
\text { mundo. }\end{array}$ & $\begin{array}{l}\text { S Toda la } \\
\text { tie| rra } \\
\text { tama } \\
\text { adios. } \\
\text { mas del se } \\
\text { todos | los } \\
\text { morantes }\end{array}$ & $\begin{array}{l}\text { teman del } \\
\text { señor toda la } \\
\text { tierra | del } \\
\text { espauorescan } \\
\text { todos los } \\
\text { moradores | } \\
\text { delo poblado }\end{array}$ & $\begin{array}{l}\text { I temed del } \\
\text { señor todos los } \\
\text { | dela tierra } \\
\text { \& tremolen } \\
\text { del quantos } \\
\text { enl mundo | } \\
\text { habitan }\end{array}$ & $\begin{array}{l}\text { (32.8) timeat } \\
\text { Dominum } \\
\text { omnis terra } \\
\text { ab eo autem } \\
\text { commoveantur } \\
\text { omnes } \\
\text { inhabitantes } \\
\text { orbem }\end{array}$ & 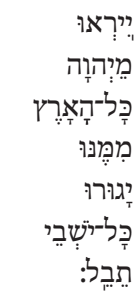 \\
\hline
\end{tabular}

En E $3_{3_{1}}$ el versículo 33.6 acaba con "compañA" y el siguiente empieza por "Como", produciéndose un salto de igual a igual "com-pañA (...) Apaña” ${ }^{18}{ }^{8}$ El texto de $\mathrm{S}_{2}$ permite reconstruir el original de la traducción, laguna en $\mathrm{E}_{3_{1}}$ que se separa notablemente del resto de las versiones ( $\underline{\mathrm{Sal}}$. 33.6-8).

En el caso siguiente (Sal. 36.I), S2 presenta una rúbrica más extensa, con más información que $\mathrm{E}_{3_{\mathrm{I}}}$ y que el resto de las traducciones, pero por sus características no puede considerarse como una laguna que pruebe que $\mathrm{E}_{3_{\mathrm{I}}}$ no copia de $\mathrm{S}_{2}$.

[36.I] el que esfuerça por el sieruo del sennor Por daujd fijo de ysay $\mathrm{S}_{2}$ ] el que efuerça por el sieruo del sennor Por daujt $\mathrm{E}_{3_{1}}$.

La laguna más importante afecta a Sal. 8o.9-Io. E3 $3_{\mathrm{I}}$ omite la parte final de 80.9 y todo el versículo siguiente:

[8o.9] \& Plantaste la [8o.Io] I | esconbraste delante dellos aRay | gaste sus Rayzes \& fincho la tierra | cubrieron $\left.\mathrm{S}_{2}\right]$ om $\mathrm{E}_{3}$

La laguna descrita en 33.7 procede de un salto de igual a igual, pero la de 80.9-Io implica la omisión de un versículo entero en $\mathrm{E}_{3_{\mathrm{I}}}$, cosa poco habitual en la cuidada copia escurialense.

\subsection{I.2 Errores}

Son muy pocos los errores que se pueden detectar y, en algunos casos, como el que sigue, no se los

I8. En E 3 $_{\text {I }}$ en Ez. I8.30 existe también una laguna por salto por homoioteleuton (Avenoza 2OI7: 296). 
puede considerar como error separativo, porque podría tratarse de una confusión paleográfica del copista de $\mathrm{E}_{3}$ :

[78.47] estruyo | con pedrisco sus vides $\left.\mathrm{S}_{2}\right]$ estruyo con pedrisco sus vidas $\mathrm{E}_{3_{\mathrm{I}}}$.

"Vidas" por "vides" es un error en $\mathrm{E}_{3_{\mathrm{r}}}$, que en principio lo descartaría como original de $\mathrm{S}_{2}$.

En el siguiente ejemplo, existen divergencias notables entre las distintas versiones, tratándose de un pasaje oscuro:

[36.3] quelo alaba ael asus ojos $\mathrm{S}_{2}$ ] fue blando esquantra eill con sus ojos E8; allana ael asus oios $\mathrm{E}_{3}$; acomete ael con los sus ojos $\mathrm{E}_{5} / \mathrm{EV}$; engañosamente andudo ante el acatamiento del $\mathrm{E}_{4}$; delezno ael con sus ojos BNM; ; engaño conlos sus oios $\mathrm{Arrag}_{2}$

La traducción de la Biblia de Cantera-Iglesias (Biblia: 1975) apunta que se trata de un versículo "difícil y diversamente interpretado", por lo que Pueyo Mena sugiere examinar las soluciones presentes en la Biblia de Ferrara (Lazar ed.: 1996), con las que se suelen alinear las traducciones de la familia de E3:

Ferrara [36.3] Porque alisó a él en sus ojos, para fallar su delito, para odiar.

Siguiendo con la propuesta de Pueyo Mena, derivada de su examen sobre la constancia de las traducciones en la resolución de las raices hebreas, E $_{3_{\mathrm{I}}}$ traduce la raiz hebrea correspondiente "חלק" como "allanar" en al menos otras 4 ocasiones (Isa. 4I.7, Sal. 5.IO, Prov. 2.I6 y Prov. 7.5), por lo que no se trataría de una lectura errónea en $\mathrm{E}_{3}$, sino de la forma natural que el traductor empleaba cuando se encontraba con esa raiz.

E $3_{\mathrm{I}}$ leyó y transcribió “allana”, pero parece que el copista de $\mathrm{S}_{2}$ (o su fuente) leyó “allaua”, por la similitud entre las formas de "u" y "n". Es decir, a partir de un "allana", $S_{2}$ (o un antecedente) confundió la consonante y realizó una interpretación simplificadora eliminando la doble consolante -ll-, lo que nos llevaría a "alaba".

En Sal. 7O.3O, en cambio, tanto $\mathrm{E}_{3_{\mathrm{I}}}$ como la $\mathrm{S}_{2}$ ofrecen lecturas erróneas, que los vinculan:

[78.30] I non se farta| ron de su deseo $\mathrm{S}_{2}$ ] se enfadaron de su deseo $\mathrm{E}_{3}$; tornaron de sus cobdiçias $\mathrm{E}_{5} / \mathrm{EV}$; fueron engañados desu deseo $\mathrm{E}_{4}$; se estrañaron de su apetito $\mathrm{BNM}_{1}$; se partieron del su deseo $\mathrm{Arrag}_{2}$; Porque alisó a él en sus ojos, para fallar su delito, para odiar Ferrara

De nuevo, según Pueyo Mena, tanto BNM como E3 ${ }_{1}$ traducían la raíz hebrea correspondiente "זור" por "estrañarse" (como verbo) o "estraño" (como sustantivo). Es probable que la traducción originalmente llevara "se estrañaron". El traductor de E $_{3_{1}}$ es muy coherente, es decir, trata de usar siempre un mismo lema castellano para el mismo lema hebreo. El "fartaron" por "ensañaron" de $\mathrm{S}_{2}$ parece contagio del versículo anterior, el 78.29: "e comieron e fartáronse mucho...”, pero el error de $\mathrm{E}_{3_{\mathrm{I}}}$ ("enfadaron” por "estrañaron”) es más difícil de explicar sin culpar a un modelo que no se leyera bien. 


\section{$5 \cdot 2.2 \mathrm{E}_{3_{\mathrm{I}}}$ no copia $\mathrm{S}_{2}$}

\subsubsection{Lagunas}

Si tenemos en cuenta las lagunas localizadas en $\mathrm{S}_{2}$, tampoco resulta posible que $\mathrm{E}_{3}{ }_{\mathrm{I}}$ copie $\mathrm{S}_{2}{ }^{19}$

En $\underline{\mathrm{Sal} .33 . \mathrm{I} 7} \mathrm{~S}_{2}$ omite un texto, por salto de igual a igual, imposible de reconstruir por $\mathrm{E}_{3_{\mathrm{I}}}$ a no ser que mediara una contaminación textual.

\begin{tabular}{|c|c|c|c|c|c|c|c|c|c|c|}
\hline E8 & GE & $E_{3_{1}}$ & $\mathrm{~S}_{2}$ & $E_{5}$ & EV & $\mathrm{E}_{4_{4}}$ & $\mathrm{BNM}_{\mathrm{I}}$ & $\operatorname{Arrag}_{2}$ & Latín & Hebreo \\
\hline $\begin{array}{l}\text { El Cauaillo } \\
\text { sera faillido } \\
\text { pora socorrer } \\
\text { | \& por } \\
\text { muchedumbre } \\
\text { de su fuerça } \\
\text { no li | brara/. }\end{array}$ & $\begin{array}{l}\text { Sallido es el } \\
\text { cavallo para } \\
\text { salut; mas en } \\
\text { el abondo de } \\
\text { la su virtut } \\
\text { non sera } \\
\text { salvo. }\end{array}$ & $\begin{array}{l}\text { I fal | sedad es } \\
\text { quel cauallo } \\
\text { es para } \\
\text { saluaçi| on \& } \\
\text { por su mucha } \\
\text { fuerça non }\end{array}$ & $\begin{array}{l}\text { falsedad es } \\
\text { para saluaçion } \\
\& \text { por } \mid \text { su } \\
\text { mucha fuerça } \\
\text { non escapa }\end{array}$ & $\begin{array}{l}\text { I falsia es el | } \\
\text { cauallo para } \\
\text { saluaçion njn } \\
\text { conla grand } \\
\text { valor | non } \\
\text { guaresçe. }\end{array}$ & $\begin{array}{l}\text { I falsya es el } \\
\text { cauallo para } \\
\text { saluaçion njn } \\
\text { conla su grant } \\
\text { valor non } \\
\text { guaresçe | }\end{array}$ & $\begin{array}{l}\text { I Engañoso } \\
\text { es el cauallo } \\
\text { para la } \\
\text { salud | con } \\
\text { abondamiento } \\
\text { de su fuerça } \\
\text { non sera | } \\
\text { saluo. }\end{array}$ & $\begin{array}{l}\text { I mentira } \\
\text { es el cauallo } \\
\text { I para la } \\
\text { saluaçion \& } \\
\text { con su mucha } \\
\text { virtud non | } \\
\text { faze escapar }\end{array}$ & $\begin{array}{l}\text { la falsedat el } \\
\text { cauallo es a } \\
\text { salua| çion } \\
\text { nin con } \\
\text { muchidunbre } \\
\text { de [su] hueste } \\
\text { non es | capa }\end{array}$ & $\begin{array}{l}(32.17) \text { fallax } \\
\text { equus ad } \\
\text { salutem in } \\
\text { abundantia } \\
\text { autem virtutis } \\
\text { suae non } \\
\text { salvabitur }\end{array}$ & 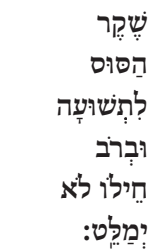 \\
\hline
\end{tabular}

La omisión de 35.5 por $\mathrm{S}_{2}$ puede tener su origen en un salto de igual a igual, puesto que 35.5 empieza "seran" en $\mathrm{E}_{3_{\mathrm{I}}}$ ("sean” en las demás versiones) y 35.6 empieza con "sea" en $\mathrm{E}_{3_{\mathrm{I}}}$ ("sean" en las demás versiones). Sal. $35 \cdot 5-6$ :

\begin{tabular}{|c|c|c|c|c|c|c|c|c|c|c|c|}
\hline $\begin{array}{l}\text { Sal. } \\
35\end{array}$ & E8 & GE & $\mathrm{E}_{3_{1}}$ & $\mathrm{~S}_{2}$ & $\mathrm{E}_{5}$ & $\mathrm{EV}$ & $\mathrm{E}_{4_{4}}$ & $\mathrm{BNM}_{1}$ & $\operatorname{Arrag}_{2}$ & Latín & Hebreo \\
\hline 5 & $\begin{array}{l}\text { Sean } \\
\text { fechos assi } \\
\text { como el } \\
\text { poluo ante } \\
\text { la faz | del } \\
\text { viento, y } \\
\text { enpuxe los } \\
\text { el angel de } \\
\text { dios, | }\end{array}$ & $\begin{array}{l}\text { Sean fechos como } \\
\text { polvo ante la faz } \\
\text { del viento. E el } \\
\text { angel del Señor } \\
\text { que los costringa. }\end{array}$ & $\begin{array}{l}\text { I seran | } \\
\text { commo } \\
\text { paja ante } \\
\text { viento \& el } \\
\text { angel de | } \\
\text { dios que los } \\
\text { rrenpuxara }\end{array}$ & & $\begin{array}{l}\text { I | Sean } \\
\text { como el } \\
\text { tamo antel } \\
\text { ujento \& } \\
\text { angel | del } \\
\text { señor los } \\
\text { persigua }\end{array}$ & $\begin{array}{l}\text { If Sean } \\
\text { como | el } \\
\text { thamo antel } \\
\text { viento \& } \\
\text { angel del } \\
\text { señor los } \\
\text { persigua. }\end{array}$ & $\begin{array}{l}\text { I Asy sean } \\
\text { commo el } \\
\text { poluo antel } \\
\text { vi } \mid \text { ento \& } \\
\text { el angel } \\
\text { de dios los } \\
\text { confonda. }\end{array}$ & $\begin{array}{l}\text { I Sean co|mo } \\
\text { tamo delante } \\
\text { viento \& el } \\
\text { angel del | } \\
\text { señor que los } \\
\text { deseche }\end{array}$ & $\begin{array}{l}\text { I sean asy } \\
\text { commo } \\
\text { el poluo } \\
\text { | delante } \\
\text { del viento } \\
\text { \& el angel } \\
\text { del señor } \\
\text { | los } \\
\text { enpuxe } \\
\text { [pene] }\end{array}$ & $\begin{array}{l}(34 \cdot 5) \text { fiant } \\
\text { tamquam } \\
\text { pulvis ante } \\
\text { faciem venti et } \\
\text { angelus Domini } \\
\text { coartans eos }\end{array}$ & 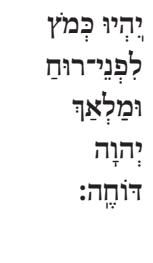 \\
\hline 6 & $\begin{array}{l}\text { La } \\
\text { Carrera } \\
\text { deillos sea } \\
\text { tiniebras } \\
\text { \& lobrego } \\
\text { [fol. } \\
\text { 228r-b] y } \\
\text { el angel } \\
\text { de dios } \\
\text { segude } \\
\text { los. }\end{array}$ & $\begin{array}{l}\text { Fecha sea la } \\
\text { carrera dellos } \\
\text { tiniebras e } \\
\text { desllanamiento; e } \\
\text { el angel del Señor } \\
\text { que los segude. }\end{array}$ & $\begin{array}{l}\text { I sea su } \\
\text { ca|mjno } \\
\text { escuro \& } \\
\text { tjnjeblas \& } \\
\text { el angel | del } \\
\text { sennor que } \\
\text { los ssegujra }\end{array}$ & $\begin{array}{l}\text { I sea su } \\
\text { camj| no } \\
\text { escuro \& } \\
\text { tinjeblas } \\
\text { \& el angel } \\
\text { | del } \\
\text { sennor } \\
\text { quelos } \\
\text { segujra }\end{array}$ & $\begin{array}{l}\text { I Sean } \\
\text { las sus } \\
\text { carre |ras } \\
\text { tini[e]bra \& } \\
\text { ocasiones } \\
\text { \& el angel } \\
\text { del señor | } \\
\text { los corra }\end{array}$ & $\begin{array}{l}\text { \$ Sean } \\
\text { las sus } \\
\text { ca| rreras } \\
\text { tjnjebra \& } \\
\text { ocasyones } \\
\& \text { angel del } \\
\text { señor los } \\
\text { corra }\end{array}$ & $\begin{array}{l}\$ \text { | las sus } \\
\text { carreras } \\
\text { sean } \\
\text { tinjebras \& } \\
\text { lobre fol | co } \\
\text { \& el angel } \\
\text { de dios los } \\
\text { confonda } \\
\text { \& los | } \\
\text { persyga. }\end{array}$ & $\begin{array}{l}\text { I Sea su via } \\
\text { escu| rana \& } \\
\text { deleznaçiones \& } \\
\text { el angel del [fol. } \\
\text { I3or-b] Señor } \\
\text { que los siga }\end{array}$ & $\begin{array}{l}\text { I sean } \\
\text { sus vias } \\
\text { tiniebra \& } \\
\text { | lobrego } \\
\text { \& el } \\
\text { angel del } \\
\text { señor los } \\
\text { perssiga }\end{array}$ & $\begin{array}{l}\text { (34.6) fiat } \\
\text { via illorum } \\
\text { tenebrae et } \\
\text { lubricum et } \\
\text { angelus Domini } \\
\text { persequens eos }\end{array}$ & 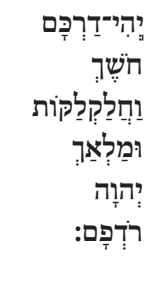 \\
\hline
\end{tabular}

La última laguna detectada afecta a una rúbrica. Si antes se ha señalado una interpolación de $\mathrm{S}_{2}$ en la rúbrica de 36r., ahora es una laguna en 8ı.ı exclusiva de $\mathrm{S}_{2}$.

[8I.I] salmo A açaff $\mathrm{S}_{2}$ ] salmo sobre la gujtarra a açaf $\mathrm{E}_{3_{\mathrm{I}}}$

Aunque no se trate de un errores separativos, estas lagunas apoyan la hipótesis de que $\mathrm{E}_{3_{\mathrm{I}}}$ no copia de $\mathrm{S}_{2}$.

$$
\text { 5.2.2.2 Variantes y errores (conjuntivos y separativos) en } \mathrm{S}_{2} \text { y } \mathrm{E}_{3_{\mathrm{I}}}
$$

Aunque las lagunas detectadas apuntan a que $\mathrm{S}_{2}$ y $\mathrm{E}_{3}{ }_{\mathrm{I}}$ no pueden ser copia el uno del otro, sino que descienden de un antecedente común directamente $\mathrm{o}$ a través de alguna $\mathrm{o}$ algunas copias

I9. En Avenoza (20I7: 296) se reseñaban dos lagunas por salto de igual a igual en S (Ez. I6.37, I6.55) y otra en la que se omitía la segunda parte de una de una coordinación Ez. i6.20 “a tus fijos (e a tus fijas)". 
intermedias, es evidente que para fijar las relaciones de parentesco los errores son las piedras de toque. ${ }^{20}$ En crítica textual es necesario ser muy cuidadoso, dado que siempre es posible la contaminación con otras fuentes, así que la forma menos arriesgada para establecer parentescos es la identificación de errores comunes. La brevedad de $\mathrm{S}_{2}$ lo hace muy difícil, pero hemos encontrado algunos errores que apuntarían hacia una relación entre $\mathrm{E}_{3}$ y $\mathrm{S}_{2}$. Para comprenderlos ha sido fundamental el aceso al trabajo de Pueyo Mena (en preparación) y los datos que nos ha proporcionado sobre la tradición en la que se inscribe la traducción representada por $\mathrm{E}_{3}$.

\section{Variantes sinonímicas:}

Divergencias que no afectan al sentido del texto ni constituyen errores significativos.

[81.2] Cantad a dios que es nuestra fortaleza $\mathrm{S}_{2}$ ] Cantad a dios sobre nuestra fortaleza $\mathrm{E}_{3}$ Cantemos $_{\mathrm{I}}$ adios dela nuestra fortaleza E5 Cantemos adios toda la nuestra fortaleza EV Ensalçad \& alegrad uos adios nuestro ayudador $\mathrm{E}_{4_{4}}$ Cantad adios nuestra fortaleza BNM ${ }_{\mathrm{I}}$ Cantad al señor nuestro ayudador Arrag.

En este caso la tradición se muestra discordante, aunque no se puede hablar de errores, ya que se trata de construcciones sinonímicas.

33.20 anpara $\left.\mathrm{S}_{2}\right]$ ayuda $\mathrm{E}_{3}$

Todas las versiones llevan "ayuda” en este versículo, pero E5 y EV añaden "anparança” ("nuestra ayuda e nuestra anparança es"). Tampoco podemos considerar "ayuda" como una variante significativa puesto que se trata de sinónimos.

36.4 atender \& de fazer bien $\left.\mathrm{S}_{2}\right]$ entender \& de fazer bien $\mathrm{E}_{3}$

La variante transmitida por $\mathrm{S}_{2}$ no se encuentra en ninguna otra de las traducciones y aunque podamos considerarla como un error, no es significativo porque el sentido no varía y se trata de expresiones sinonímicas.

35.3 quebrante conel ayuno mj anjma $\mathrm{S}_{2}$ ] quebre me conel ayuno mi anjma $\mathrm{E}_{3_{\text {I }}}$

En este versículo el resto de traducciones opta por otros verbos como "penar”, "omillar”, "atormentar" o "afligir": penaua mi alma con ayuno E8 penaua con ayuno la mj anima E5 EV ommjllaua en ayuno la mi alma $\mathrm{E}_{4}$ atormente con ayuno mj alma $\mathrm{BNM}_{\mathrm{I}}$ afligi con ayuno la mi anima Arrag $_{2}$. La traducción de E 3 $_{1}$ prefiere el verbo "quebrar" y las diferencias en la forma transmitida por $\mathrm{S}_{2}$ pueden deberse a un error paleográfico surgido de la confusión entre -ante y -eme.

\section{Variantes separativas:}

[33.2] con gujtarra [[de]] x[** ]erda $\left.\mathrm{S}_{2}\right]^{21}$ con guitarra dezena $\mathrm{E}_{3_{\mathrm{I}}}$

Solamente $\mathrm{E}_{3_{\mathrm{I}}}\left(\mathrm{y} \mathrm{S}_{2}\right)$ llevan "guitarra" donde el resto de las versiones transcriben "salterio" E8, GE, E $4_{4}, \operatorname{Arrag}_{2}$, o "estrumente" E5 EV. El mal estado de $\mathrm{S}_{2}$ no permite saber hasta que punto

20. Las lagunas y errores detectados en la comparación de $\mathrm{S}_{\mathrm{I}}$ y $\mathrm{E}_{3_{\mathrm{I}}}$ conducen a esta misma hipótesis (Avenoza 2OI7: 295-7).

2I. Pasaje en muy mal estado. La preposición “de” fue añadida posteriormente en el interlineado. 
coincidía con E $3_{\mathrm{I}}$, más allá de optar por "guitarra”.

\section{Errores separativos:}

[8o.8] alunbra tu carrera $\mathrm{S}_{2}$ ] alunbra tu cara $\mathrm{E}_{3} \mathrm{BNM}_{\mathrm{r}}$; rrelunbra la tu faz $\mathrm{E}_{5} / \mathrm{EV}$; demuestra la tu $\mathrm{faz}_{4} \mathrm{E}_{4}$; alunbra las tus fazes Arrag.

$\mathrm{S}_{2}$ es el único testimonio entre las versiones bíblicas que presenta la lectura anómala "carrera". Se trata de un error que, aunque podría tener origen paleográfico, ${ }^{22}$ apoyaría que $\mathrm{E}_{3_{\mathrm{I}}}$ no es copia de S2.

\section{Variantes y errores conjuntivos:}

Al explicar las características de esta copia, se han expuesto antes las variantes más significativas, como la que afecta a Sal. 36.3 , probablemente surgida en el antecedente de $\mathrm{E}_{3} \mathrm{y} \mathrm{S}_{2}$ que provoca un error de origen paleográfico en $\mathrm{S}_{2}$ y corrobora que $\mathrm{E}_{3}$ no es copia de $\mathrm{S}_{2}$.

Por lo que respecta a los errores, como se ha expuesto antes, el que en Sal. 78.30 E $3_{\mathrm{r}}$ y $\mathrm{S}_{2}$ tengan problemas de lectura en el mismo punto, apunta a que el problema se remonta a un antecedente común, por lo que lo consideramos como un error conjuntivo.

\section{Otros errores:}

En 78.50 "passaua" $\left(\mathrm{S}_{2}\right)$ y "pesaua" $\left(\mathrm{E}_{3}\right)$ contrastan con la disparidad de las interpretaciones del resto de los testimonios. E3, traduce en cualquier contexto el verbo פלס como "pesar" (equivalente a "sopesar, considerar, meditar") y BNM, que emplea una técnica de traducción similar, coincide con él. Fiel a su fijación por reproducir siempre los lemas hebreos por un lema concreto castellano y no otro, mantiene el verbo "pesar" allí donde el sentido del texto sería "dio rienda suelta a su ira" (Pueyo Mena \& Enrique-Arias 2OI3: 202-O5; Enrique-Arias \& Pueyo Mena 2OI7: 6o). El copista de $\mathrm{S}_{2}$, perplejo ante lo que pudo leer en su antecedente, optó por una lectio facilior "pasaua" atraído por el sustantivo "camino" que le sigue y que tendría más sentido para él.

\begin{tabular}{|c|c|c|c|c|c|c|c|c|c|}
\hline GE & $E_{3_{1}}$ & $\mathrm{~S}_{2}$ & $\mathrm{E}_{5}$ & EV & $\mathrm{E}_{4_{4}}$ & $\mathrm{BNM}_{1}$ & $\operatorname{Arrag}_{2}$ & Latín & Hebreo \\
\hline $\begin{array}{l}\text { Carrera fizo } \\
\text { al sendero de } \\
\text { la su ira; non } \\
\text { perdono de } \\
\text { la muerte de } \\
\text { las sus almas } \\
\text { e cerco las } \\
\text { sus bestias de } \\
\text { muerte. }\end{array}$ & $\begin{array}{l}\text { I pesaua } \\
\text { camjno para | } \\
\text { su yra \& non } \\
\text { deuedo dela } \\
\text { muerte | sus } \\
\text { anjmas E sus } \\
\text { anjmas ala | } \\
\text { mortandad } \\
\text { entrego }\end{array}$ & $\begin{array}{l}\text { pasaua } \\
\text { camj|no para } \\
\text { su yra \& non } \\
\text { deuedo dela } \\
\text { | muerte sus } \\
\text { anjmas \& sus } \\
\text { anjmas | ala } \\
\text { mortandat } \\
\text { entrego }\end{array}$ & $\begin{array}{l}\text { I frio fran |ca } \\
\text { mente por } \\
\text { su saña non } \\
\text { escuso dela } \\
\text { muer| te las } \\
\text { sus almas \& } \\
\text { las sus uidas } \\
\text { al mata| dor } \\
\text { acordo. }\end{array}$ & $\begin{array}{l}\text { I frio franca } \\
\text { mente por } \\
\text { su saña non } \\
\text { escuso dela(s) } \\
\text { mu| erte las } \\
\text { sus almas \& } \\
\text { las sus uidas } \\
\text { al matador } \\
\text { aguardo }\end{array}$ & $\begin{array}{l}\text { I fizo ca| rrera al } \\
\text { sendero de su yra } \\
\text { non perdono. de } \\
\text { | muerte las sus } \\
\text { almas \& las sus } \\
\text { vidas en | muerte } \\
\text { ençerro. }\end{array}$ & $\begin{array}{l}\text { I fue pesa | da } \\
\text { su via con } \\
\text { su yra non } \\
\text { deuedo dela } \\
\text { mu | erte su } \\
\text { alma dellos \& } \\
\text { sus anjmaljas | } \\
\text { ala pestilençia } \\
\text { entrego }\end{array}$ & $\begin{array}{l}\text { I adereço el } \\
\text { sendero dela su } \\
\text { yra non | escuso } \\
\text { de muerte las } \\
\text { sus animas \& las } \\
\text { sus | vidas en } \\
\text { pestilençia çerro }\end{array}$ & $\begin{array}{l}(77.50) \text { viam } \\
\text { fecit semitae } \\
\text { irae suae } \\
\text { non pepercit } \\
\text { a morte } \\
\text { animarum } \\
\text { eorum et } \\
\text { iumenta eorum } \\
\text { in morte } \\
\text { conclusit }\end{array}$ & 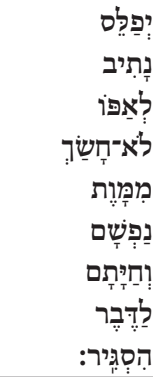 \\
\hline
\end{tabular}

22. El antígrafo de $\mathrm{S}_{2}$ llevaría “cara”, pero en la línea inferior pudo haber una tilde de abreviación que el copista confundió con la vírgula (2) que se suele emplear para la abreviatura de -er-y transcribió "carrera". 
$5 \cdot 2.3$ Variantes o errores de menor entidad

\subsubsection{Género y número}

34.2O los $\mathrm{S}_{2}$ ] lo $\mathrm{E}_{3} ; 78.28$ \& echolos $\mathrm{S}_{2}$ ] \& echolas $\mathrm{E}_{3} ; 78.29$ los $\mathrm{S}_{2}$ ] les $\mathrm{E}_{3} ; 78.44$ sangres $\mathrm{S}_{2}$ ] sangre $\mathrm{E}_{3} ; 7_{1} 8.55$ gentios $\mathrm{S}_{2}$ ] gentio $\mathrm{E}_{3} ;$;o.6 lagrima $\mathrm{S}_{2}$ ] lagrimas $\mathrm{E}_{3} ;$; 8o.II y 8o.I2 Ramos $\mathrm{S}_{2}$ ] rramas $\mathrm{E}_{3}$.

5.2.3.2 Artículos, determinantes, preposiciones, pronombres, adverbios o conjunciones

33.I5 que $\mathrm{S}_{2}$ ] el que $\mathrm{E}_{3} ; 33 . \mathrm{I} 8$ alos $\mathrm{S}_{2}$ ] con $\operatorname{los} \mathrm{E}_{3} ; 33.20$ que $\mathrm{S}_{2}$ ] e que $\mathrm{E}_{3} ; 33.2 \mathrm{I}$ nuestra $\mathrm{S}_{2}$ ] ssu $\mathrm{E}_{3} ; 34.5$ Re[...]iolos $\mathrm{S}_{2}$ ] rrespondiome $\mathrm{E}_{3} ; 34.7$ [*** $^{* *}$ e mezquino $\mathrm{S}_{2}$ ] es mezqujno $\mathrm{E}_{3_{1}}$ (las demás versiones incluyen un determinante); $34.2 \mathrm{O}$ males (...) todos los escapara $\left.\mathrm{S}_{2}\right]$ males (...) todos lo escapara $\mathrm{E}_{3} ; 35.7$ en balde $\mathrm{S}_{2}$ ] en de balde $\mathrm{E}_{3}$; 35 . IO escapas el mezquino $\mathrm{S}_{2}$ ] escapas al mezquino $\mathrm{E}_{3} ; 35 . \mathrm{I} 2$ males por bienes $\left.\mathrm{S}_{2}\right]$ mala por buena $\mathrm{E}_{3} ; 78.40$ quanto $\mathrm{S}_{2}$ ] quando $\mathrm{E}_{3} ; 78.54$ troxolos (...) \& aqueste monte $\mathrm{S}_{2}$ ] troxolos (...) a aqueste monte $\mathrm{E}_{3} ;$;.I ensuziaron en tu palaçio $\mathrm{S}_{2}$ ] ensuziaron el tu palaçio $\mathrm{E}_{3} ;$; 79.4 denuesto a $\mathrm{S}_{2}$ ] denuesto de $\mathrm{E}_{3} ;$; 80.18 de tu diestra \& sobrel fijo del omne $\mathrm{S}_{2}$ ] de tu diestra que sobrel fijo del omne $\mathrm{E}_{3}$.

En 33.2I, el error en $\mathrm{S}_{2}$ pudo surgir por la atracción del posesivo plural repetido ante el sustantivo de la frase anterior: "se alegrara nuestri [sic] coraçon". En 78.4O "quando" de E $3_{\text {I }}$ es un error, pero puede tener un origen paleográfico, puesto que la frase podría aceptar ambas formas sin que fuera advertido.

\section{$5 \cdot 2 \cdot 3 \cdot 3$ Formas verbales}

34.5 [..] escapo $\mathrm{S}_{2}$ ] me escapa $\mathrm{E}_{3} ; 34.7$ llama $\mathrm{S}_{2}$ ] llamo $\mathrm{E}_{3} ; 33.8$ Reçelan $\mathrm{S}_{2}$ ] rreçelaran $\mathrm{E}_{3} ; 35 . \mathrm{I} 3$ adolesco $\mathrm{S}_{2}$ ] adolesçe $\mathrm{E}_{3}{ }_{\mathrm{I}}\left(\right.$ error en $\mathrm{E}_{3}$ ); 35.I4 ando $\mathrm{S}_{2}$ ] ande $\mathrm{E}_{3} ; 35 . \mathrm{I} 8$ loarte $\mathrm{S}_{2}$ ] loare $\mathrm{E}_{3} ; 35.23$ ] Recuerda $\mathrm{S}_{2}$ ] rrecuerdate $\mathrm{E}_{3} ; 78.39$ nenbrose que (..) eran esprito $\mathrm{S}_{2}$ ] nenbrose que (...) era espiritu $\mathrm{E}_{3}$; 8o.r9 tiraremos $\left.\mathrm{S}_{2}\right]$ tiremos $\mathrm{E}_{3_{\mathrm{I}}}$.

\subsubsection{Errores por duplografía}

35.I] guerrea con | los que guerrean comj | go guerrea con los que | guerrean comjgo S2; 35.3] dy | mj mj anjma $\mathrm{S}_{2}$

\section{$5 \cdot 2 \cdot 3 \cdot 5$ Onomástica y toponomástica}

34.I abimeleque $\mathrm{S}_{2}$ ] alimeleque $\mathrm{E}_{3}$ (palabra escrita en la rúbrica); 78.5I ham $\mathrm{S}_{2}$ ] Cam $\mathrm{E}_{3}$; 78.5I] egibtanos $\mathrm{S}_{2}$ ] agibtanos $\mathrm{E}_{3} ; 78.67$ de esfraym $\mathrm{S}_{2}$ ] defrayme $\mathrm{E}_{3} ;$; 80.3 efraym(e)] frayme $\mathrm{E}_{3_{\mathrm{I}}}$

\section{Recapitulando}

$\mathrm{H}$ asta aquí se ha ofrecido una sumaria presentación del nuevo fragmento bíblico recuperado, que es una copia que desciende directa o indirectamente del mismo antígrafo que $\mathrm{E}_{3}$. Las lagunas y errores detectados apuntan a que ambos tienen un antecedente común, y que no son copia el uno del otro, sin que se pueda aportar más información al respecto. La brevedad de $S_{2}$, y la escasez de errores que se puedan considerar como realmente significativos en estos pasajes, no permiten ir más allá.

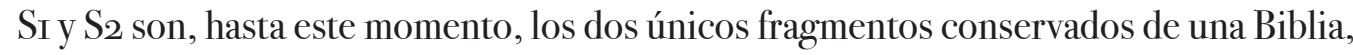


probablemente completa, que estuvo en el monasterio de Santa María de la Sisla, al menos a finales del s. XV, cuando sus bifolios de pergamino fueron reutilizados para encuadernar documentación del monasterio.

\section{${ }_{7}$ Transcripción paleográfica de Sal. 32.II-36.7 y 78.25-8I.2}

\section{I Normas de transcripción}

Se respeta la presentación del texto, sin intervenir en las grafías, en el uso de mayúsculas y minúsculas, la puntuación o la separación y unión de palabras. En la resolución de las abreviaturas se emplea la cursiva. Se transcribe la abreviatura de la conjunción como \& y el calderón con 』. Se señalan los cambios de línea con | . Las partes del texto ilegibles por deterioro del soporte se presentan entre corchetes [ ]; el número de * dentro de los corchetes corresponde al número de caracteres perdidos o ilegibles. En los casos en los que se reconstruye una letra o grupo de letras entre [ ], se siguen las formas visibles de las astas ascendentes y descendentes, los espacios que ocupan, las formas cóncavas y convexas de la escritura, y los usos gráficos del copista. En aquellos casos en los que el copista ha añadido una palabra o letra en el interlineado aparece en el texto entre [[ ]]. Se reproducen los textos tachados entre paréntesis ( ). Sigue un [sic] a las formas anómalas presentes en el fragmento. En el aparato de variantes se señalan las lecturas de $\mathrm{E}_{3_{\mathrm{I}}}$ cuando existen divergencias respecto de $\mathrm{S}_{2}$ o cuando el texto del fragmento está deteriorado. No se señalan las divergencias en vocales átonas e/i, u/o (fizieron $\mathrm{S}_{2} /$ fezieron $\mathrm{E}_{3}$; pusieron $\mathrm{S}_{2} /$ posieron $\mathrm{E}_{3}$; Capitolo $\mathrm{S}_{2} /$ Capitulo $\mathrm{E}_{3}$; aportellaste $\mathrm{S}_{2}$ / aportillaste $\mathrm{E}_{3}$ ), en consonantes finales (cantad $\mathrm{S}_{2}$ / cantat $\mathrm{E}_{3_{1}}$; merced $\mathrm{S}_{2} /$ merçet $\mathrm{E}_{3_{1}}$; maldat $\mathrm{S}_{2} /$ maldat $\mathrm{E}_{3}$; mortandat $\mathrm{S}_{2} /$ mortandad $\mathrm{E}_{3}$; heredat $\mathrm{S}_{2} /$ heredad $\mathrm{E}_{3}$; sanidat $\mathrm{S}_{2} /$ sanidad $\mathrm{E}_{3}$; verdat $\mathrm{S}_{2} / \operatorname{verdad} \mathrm{E}_{3_{\mathrm{I}}}{ }^{23}$ en grupos consonánticos (creçio $\mathrm{S}_{2} /$ cresçio $\mathrm{E}_{3}$ ), o en confusión de líquidas (anjmanja $\mathrm{S}_{2}$ / anjmalia $\mathrm{E}_{3}$ ), siempre que no impliquen variación en la interpretación del texto (pasaua $\mathrm{S}_{2} /$ pesaua $\mathrm{E}_{3}$; vides $\mathrm{S}_{2} /$ vidas $\mathrm{E}_{3_{\mathrm{I}}}$ ) o alteren modo, tiempo o persona en los tiempos verbales.

Una versión de este texto según las normas de Bibliamedieval.es se enviará a los compiladores de la página y estará allí disponible en breve. El texto fue transcrito a partir del original mientras servía de encuadernación al legajo, y se revisó tras ser separado del liber tradens. Para la lectura de las partes en peor estado he recurrido a una lámpara ultravioleta. Agradezco a los responsables del AHN la amabilidad con la que acogieron la solicitud de intervención sobre esta cubierta, y las facilidades que han dado para consultar el fragmento en todo momento.

\subsection{Texto: AHNClero Regular-Secular, L. 14734, cubiertas}

$$
\text { 7.2.I Fragmento A }
$$

[f. ccclxvj $\left.{ }^{\text {ra }}\right]$

[32.II] conel sennor \& gozad los justos \& can $\mid$ tad todos los derecheros de coraçon [33.I] [*]an| tad

23. No existe una distribución sistemática - $\mathrm{d}_{2} /$ - $-\mathrm{E}_{3_{\mathrm{I}}}$, aunque esta sea la solución predominante, puesto que también se documentan "falsedad" y "verdat" en $\mathrm{S}_{2}$ y E $3_{\mathrm{r}}$. 
$\left[{ }^{* *}\right]\left[{ }^{* * *}\right]$ xxiij $[* * * * * * * *]^{24} \mid \mathrm{C}(3)$ antad justos conel sennor $\mid$ alos derecheros es fermoso | el loor

[33.2] I load al sennor con | $1\left[{ }^{*}\right] \mathrm{ud}^{25}$ con gujtarra [[de] $\mathrm{x}^{* * *}{ }^{* *} \mathrm{rda}^{26} \mid$ le cantad a el

[33.3] $\left.\mathrm{ca}^{* * *}\right] \mathrm{al}^{27}$ sennor canto | nueuo adereçad d[ $\left.{ }^{* * *}\right]$ nner con corneta ${ }^{28}$ |

[33.4] que derechera es la palabra del sennor | \& toda su obra es con verdat

[33.5] I ama | justiçia \& juyzio dela merçet de dios es | llena la tierra

[33.6] I por la palabra del | sennor los çielos se fizieron \& por el espi | rito de su boca toda su conpanna

[33.7] פ el | que Apaña ${ }^{29}$ commo vn monton las | aguas dela mar el que pone en tesoros | los abismos

[33.8] temeran del sennor todos | los dela tierra del se Reçelan todos [***] ${ }^{30}$

| moradores del mundo

[33.9] que lo quel dix $\left.\left[^{*}\right]^{* * *}{ }^{*}\right]^{\text {I }} \mid$ \& lo quel mando estudo

[33.Io] el señor priuo ${ }^{32} \mid$ el consejo delas gentes E quebran[**] $\operatorname{los}^{33} \mid$ pensamjentos delos pueblos [33.II] el consejo | del sennor para sienpre estara e los pen | samjentos desu coraçon de generaçi| on a generaçion

[33.I2] bien auenturado | es el gentio quel sennor es su dios E | el pueblo que lo escogio en herençia | para ssy

[33.I3] delos çielos mj[**] ${ }^{34}$ el sennor | vido atodos los fijos delos [****] ${ }^{35}$

[33.I4] del | aderesçamjento desu morada mj[***] | todos ${ }^{36}$ los moradores dela tierra

[33.I5] que ${ }^{37} \mid$ crio en vno su coraçon el que entien $\mid$ de todas sus obras

[33.I6] I non es el Rey | saluo con mucha gente njn el barra | gan non escapa por mucha fuerça |

[33.I7] [ ${ }^{*}$ ] falsedad es $^{3^{8}}$ para saluaçion \& por | su mucha fuerça non escapa

[33.I8] פ ahe | el ojo del sennor es alos ${ }^{39}$ que del temen | \& los que esperan su merçet

[33.I9] para es | capar dela muerte sus anjmas \& para | les dar vida enla fanbre

[33.20] nuestra anj | ma espera al sennor que ${ }^{40}$ nuestra anpara ${ }^{4 \mathrm{~L}} \mathrm{E} \mid$ nuestro escudo es

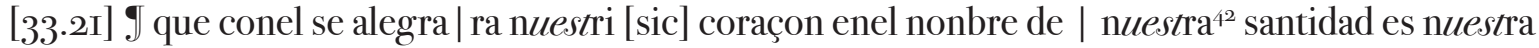

24. [**]n[ [*]ad [**] [****] xxiij [********] I Capitulo .xxxiij E ${ }_{3}^{* *}$. La línea de la rúbrica está muy deteriorada en $\mathrm{S}_{2}$ por coincidir con el doblez del pergamino y estar muy desgastado: solamente se distinguen algunos caracteres en $\mathrm{S}_{2}$; en este caso, y en todos los siguientes, anotamos el texto que transmite $\mathrm{E}_{3}$.

25. la[*]d] laud E3I.

26. con gujtarra de [ $\left.^{* *}\right]$ erda] con guitarra dezena $\mathrm{E}_{3}$.

27. $\left.\mathrm{ca}^{* * * *}\right]$ al ] cantat al $\mathrm{E}_{3}$.

28. adereçad $\mathrm{d}\left[{ }^{* *}\right] \mathrm{n} n$ er con corneta] adereçad de tanner con corneta $\mathrm{E}_{3}$.

29. como el que Apaña como un montón de aguas] Commo | vn monton las aguas dela mar el | que pone en thesoros los abismos $\mathrm{E}_{3_{1}}$.

30. Reçelan todos [***] ] rreçelaran todos $\operatorname{los} \mathrm{E}_{3_{1}}$.

3. $\operatorname{dix}\left[{ }^{*}\right][* * *]$ dixo fue $\mathrm{E}_{3}$.

32. priuo] priua $\mathrm{E}_{3}$.

33. quebran[ $\left.\left.{ }^{*}{ }^{*}\right] \operatorname{los}\right]$ quebranto los $\mathrm{E}_{3_{1} \text {. }}$.

$\left.\left.34 \cdot \mathrm{mj}^{* *}\right]\right]$ mjro $\mathrm{E}_{3}$.

35. [***]] omnes $\mathrm{E}_{3}$.

36. mj[***] todos] mjro a todos $\mathrm{E}_{3}$.

37. que] g el que $\mathrm{E}_{3}$.

38. [ ${ }^{*}$ ] falsedad es] falsedad es quel cauallo es $\mathrm{E}_{3}$.

39. alos] con los $\mathrm{E}_{3_{1}}$.

40. que] e que $\mathrm{E}_{3_{\mathrm{I}}}$.

4I. anpara] ayuda $\mathrm{E}_{3}$.

42. nuestra] ssu $\mathrm{E}_{3}$. 
fuzia

[33.22] sea la | tu merçet sennor sobre nos commo | esperamos aty. [34.I] Capitulo [*****]j. 43

[f. ccclxvj ${ }^{\text {rb }}$ ]

a daujd quando demudo su Razon ante | abimeleque ${ }^{44} \&$ le desterro E se ffue |

$[34.2] \mathrm{O}(3)$ be $\left[{ }^{*}\right] \operatorname{ecce}\left[{ }^{* * * * * * * * * * * * *}\right]^{45}$ | ora $\left.\mathrm{S}^{* * * * * *}\right]^{46}$ es la ssu | loor en $\left[{ }^{* * * *}{ }^{47}\right.$ boca [34.3] al se $\mid$ nnor loa $\left.{ }^{* * * *}\right]$ anjma ${ }^{4}{ }^{8} \mathrm{o} \mid$ yran los omjldes \& alegrarsean |

[34.4] I engrandesçed el sennor comjgo E | ensalçaremos su nonbre en vno |

[34.5] I Requeri al sennor \& Re[**]dio l(o)e ${ }^{49} \&$ de $\mid$ todos mjs mjedos me escapo ${ }^{50}$

[34.6] $9 \mathrm{mj} \mid \operatorname{rad}$ ael \& corred [***] [***] Rostros ${ }^{5 \mathrm{I}}$ non $\mid$ se auergonç[ $\left.{ }^{* * * *}\right]^{52}$

[34.7] [*****] [*] ezquino ${ }^{53} \mid 1$ lama ${ }^{54} \&$ el $\operatorname{sen} n[* *]$ lo [***]55 \& de todas $\mid$ sus angustias lo $\mathrm{S}[* * *]^{56}$

[34.8] פ posa el | angel del sennor [ $\left.{ }^{* * *}\right] \operatorname{delos}^{57}$ que $\mid$ temen del $\left[{ }^{* * *}\right]^{5^{8}}$

[34.9] Razonad | \& ved que [********] sennor 59 bien|auenturado [********] que Se $^{60}$ abri|ga $[* * *]^{6 \mathrm{r}}$

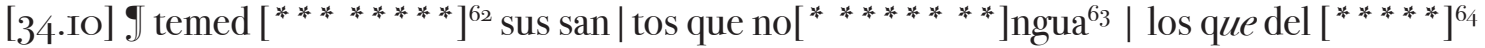

[34.II] $\left.\int \operatorname{los} \operatorname{leones}^{65} \mid \operatorname{enpo[***************}\right] \&^{66} \operatorname{los} \mid[* * *] \operatorname{Reg}[* * * * * * * * * * * *$

$* * *] \operatorname{les}^{67} \mid$ mengua $[* * * * * * *]^{68}$

$\left.[34 . \mathrm{I} 2]]^{* * * * *}\right]^{69}$ fijos $\mid$ oydme el te $[* * * * * * * * * *]^{70}$ abe $\left[{ }^{* * * *}\right]^{71}$

43. Capitulo [*****]j.] capitulo .xxxiiij. ${ }^{\circ} \mathrm{E}_{3_{\mathrm{I}}}$.

44. abimeleque] alimeleque $\mathrm{E}_{3}$.

45. O(3)be[ $\left[{ }^{*}\right]$ eçe[***] ora] Obedecere al sennor en toda ora $\mathrm{E}_{3_{\mathrm{I}}}$.

46 . ora $\mathrm{S}[* *]]$ ora sienpre $\mathrm{E}_{3}$.

47. en $\left[* * *\right.$ ] boca] en la mi boca $\mathrm{E}_{3_{1}}$.

48. loa[***] anjma] loara mj anjma $\mathrm{E}_{3}$.

49. $\left.\operatorname{Re}\left[{ }^{* *}\right] \mathrm{d}\left[{ }^{*}\right] \mathrm{o}(\mathrm{o}) \mathrm{e}\right]$ rrespondiome $\mathrm{E}_{3}$. La (o) está subpuntuada en $\mathrm{S}_{2}$.

5o. escapo] escapa $\mathrm{E}_{3}$.

$5^{\text {I. }}\left[{ }^{* * *}\right]\left[{ }^{* *}\right]$ Rostros] con vuestros Rostros $\mathrm{E}_{3_{\mathrm{r}}}$.

52. auergonç[***]] auergonçaran $\mathrm{E}_{3}$.

53. [*****] [ ${ }^{*}$ ] ezquino] es mezqujno $\mathrm{E}_{3}$.

54. llama] llamo $\mathrm{E}_{3}$.

55. el sen $n\left[* *\right.$ lo [***] \&] el sennor lo oyo \& $\mathrm{E}_{3}$.

$56 . \mathrm{s}[* * *]$ saluo] \& $\mathrm{E}_{3}$. Ilegible en $\mathrm{S}_{2}$.

$57 .{ }^{* * *}$ ] delos] derredor delos $\mathrm{E}_{3}$. Ilegible en $\mathrm{S}_{2}$ un número indeterminado de caracteres.

$\left.5^{8 .}\left[{ }^{* *}\right]\right]$ \& escapalos $\mathrm{E}_{3}$. Ilegible en $\mathrm{S}_{2}$ un número indeterminado de caracteres.

59. [***] sennor] bueno es el sennor $\mathrm{E}_{3}$. Ilegible en $\mathrm{S}_{2}$ un número indeterminado de caracteres.

$60 .\left[* * * * * *\right.$ ] que] es el omne que $\mathrm{E}_{3_{1}}$.

6I. [***]] a el E3.

$62 .[* * * * * * *]]$ del sennor $\mathrm{E}_{3}$.

63. no[*******]ngua] non avran mengua $\mathrm{E}_{3}$.

$64 .[* * * *]]$ temen del $\mathrm{E}_{3}$.

65. Esta línea y las dos siguientes tienen un agujero, reparado con adición de papeljapón.

66. enpo[**************] \&] enpobreçen \& han fanbre \& $\mathrm{E}_{3}$.

67. $\operatorname{los} \mid[* * *] \operatorname{Req}[* * * * * * * * * * * * * *]$ les] los que rrequjeren al sennor non les $\mathrm{E}_{3}$.

68. [*******]] todo bien $\mathrm{E}_{3}$.

69. [*****]] catat $\mathrm{E}_{3}$.

7o. te $[* * * * * * * * * *]$ temor de dios vos $\mathrm{E}_{3}$.

7. abe[***]] abezare $\mathrm{E}_{3}$. Esta línea y las tres siguientes tienen una rotura, reparada con adición de papel japón.

Las líneas que siguien son prácticamente ilegibles. 
[34.I3] פ qujen [***] | ver bien ${ }^{72}$

[34.I4] guar[********] de ${ }^{73} \mid$ maldat \& [***] ${ }^{74} \mid$

$[34 . I 5]$ I tirate $\operatorname{del}[* * * * * * * * * *] 5$ busca $\mid[* *]$ paz $\&[* * * * * *]^{6}$

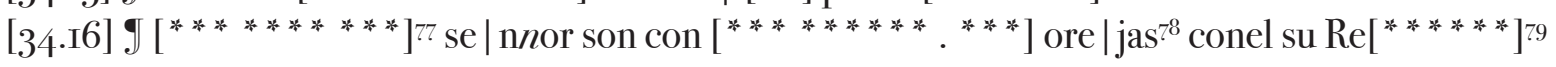

[34.I7] I la sanna | del sennor es [*******] fazen ${ }^{80}$ mal | para tajar dela [*******]

men $\mid$ braçion $^{81}$

[34.18] [ [********] el $\mathrm{I}^{82} \operatorname{sen} n$ or | los oyo \& de to[*********] stias $^{83} \mid$ los escapo

$[34 \cdot \mathrm{Ig}][* * * * * * * * * * * *] n \mathrm{r}^{84}$ de $\mid$ los quebrantados de $\operatorname{co}[* * * * *] \operatorname{los}^{85} \mid$ majados de

espiritu [***** $\operatorname{ran}^{86}$

[34.20] | muchos son los m[*]les del ${ }^{87}$ justo | \& de todos $\operatorname{los}^{88}$ escapara el sennor |

[34.2I] guarda todos los huesos que | vno dellos n[******]bro ${ }^{89}$

[34.22] mata| ra al malo la maldad \& los que |

\section{[f. ccclxvj ${ }^{\mathrm{va}}$ ]}

aborresçieron [**] j[*]sto seran estruydos |

[34.23] [***] el anjma de sus sier|uos [***]yran todos los que | se abrigan [***] ${ }^{\text {[0 }}$

[35.I] [ [ ${ }^{*}$ apitolo $^{91}$.xxxv. adaujd | P(4) [****] ${ }^{92}$ sennor con los que pele |[***]omjgo ${ }^{93}$ guerrea con | los que guerrean comj | go guerrea con los que | guerrean comjgo ${ }^{94}$.

[35.2] I traua de man | para \& adaraga \& leuantate en mj | ayuda

72. qujen [***] | ver bien] qujen es el omne que ha voluntat dela vida \& que quiere dias para ver bien $\mathrm{E}_{3}$. Está tan deteriorado en $\mathrm{S}_{2}$ que no podemos saber cuántos caracteres se han perdido ni se puede asegurar si conservaba el pasaje "voluntad dela vida \& que quiere dias para".

73. guar[*********] de] guarda tu lengua de $\mathrm{E}_{3}$. Ilegible en $\mathrm{S}_{2}$. Esta línea y las tres siguientes tienen una rotura, reparada con adición de papel japón. Las líneas que siguien son prácticamente ilegibles.

74. [***]] tu beços de fablar arte $\mathrm{E}_{3}$. Absolutamente ilegible en $\mathrm{S}_{2}$. Este versículo lleva soluciones diferentes en las demás traducciones: E8 “tus labros no fablen engaynno”, GE3 “tus labros que non fablen engaño”, E5/EV "los tus beços de fablar trayçion", E4 "los tus labros non fablen engaño", BNM “\& tus beços de fablar engaño", Arrag. "los tus labios de arte fablar".

75. $[* * * * * * * * *]$ mal \& faz bien $\mathrm{E}_{3}$.

76. [**] paz \& [******]] la paz \& siguela $\mathrm{E}_{3}$.

77. $[* * * * * * * * *] \operatorname{los}$ oios del $\mathrm{E}_{3_{1}}$.

78. [************] orejas] los justos \& sus orejas $\mathrm{E}_{3_{1}}$. Ilegible en $\mathrm{S}_{2}$.

79. $\operatorname{Re}[* * * * *]]$ rreclamor $\mathrm{E}_{3_{1}}$.

8o. [*******] fazen] enlos que fazen $\mathrm{E}_{3}$.

8I. [*******]menbraçion] tierra su rremenbraçion $\mathrm{E}_{3}$.

82. [********] el] rreclaman \& el E $3_{1}$.

83. to $[* * * * * * * *]$ stias] todas sus angustias $\mathrm{E}_{3_{1}}$.

$84 .[* * * * * * * * * * * *]$ nor] çercano es el sennor $\mathrm{E}_{3_{1}}$.

$85 . \mathrm{co}[* * * * *] \operatorname{los}]$ coraçon $\&$ alos $\mathrm{E}_{3}$.

86. [****]ran] saluaran $\mathrm{E}_{3}$.

87. $\mathrm{m}\left[{ }^{*}\right]$ les] males $\mathrm{E}_{3}$.

88. los] lo $\mathrm{E}_{3}$.

89. $\mathrm{n}[* * * * * *]$ bro] non se quebro $\mathrm{E}_{3}$.

9о. $[* * *]$ el anjma de sus sier $\mid \operatorname{uos}\left[* * *\right.$ ] ${ }^{* * a n}$ todos los que | se abrigan [***] 9 rredemjra el sennor el anjma de sus sieruos \& non se estruyran todos los que se abrigan ael E $3_{3_{1}}$. En $\mathrm{S}_{2}$ el pergamino está arrugado y hay roturas; por el estado del soporte no se puede indicar el número concreto de caracteres perdidos.

9г. [**]pitolo] Capitolo $\mathrm{E}_{3}$.

92. $\mathrm{P}(4)[* * *]]$ Pelea $\mathrm{E}_{3}$.

93. pele $\mid\left[* *\right.$ ] ${ }^{*}$ omjgo] pelean comjgo $\mathrm{E}_{3_{1}}$.

94. guerrea con | los que guerrean comj | go guerrea con los que | guerrean comjgo] guerrea con los que guerrean comjgo $\mathrm{E}_{3_{\mathrm{I}}}$. 
[35.3] \& saca lança \& çierra al en | cuentro delos que me siguen dy | por mj mj ${ }^{95}$ anjma tu saluaçion ${ }^{96}$ [35.4] I A | uergonçarsean \& bituPeriar sean | los que buscan mj Anjma torna |ran atras \& vitupiarsean los que | Piensan contra mj mal

[35.5] om.

[35.6] sea su camj | no escuro \& tinjeblas \& el angel | del sennor quelos segujra

[35.7] que en balde ${ }^{97} \mid$ escondier[ $\left.{ }^{* * *}\right] \operatorname{ara}^{98}$ mj el foyo dela $\mid$ su Red en $b\left[{ }^{* * * *}{ }^{99}\right.$ sacaron para mj A | njma

[35.8] vengale mala sonada ${ }^{\text {Ioo }}$ donde | non sepa \& su Red que escondio lo | prendera con asonada ca era en | ella

[35.9] \& mj anjma se alegrara | conel sennor \& gozara con su salua | çion

[35.IO] Todos mjs huesos diran se $\mid$ nnor quien ay commo tu que esca| pas el ${ }^{\text {Ior }}$ mezquino del que es mas fu | erte quel \& el mezquino \& deseoso del | que lo Roba

[35.II] leuantense ${ }^{\mathrm{IO2}}$ testigos | por Robo lo que non se me pregun | tan

[35.I2] 9 pechanme males por bienes ${ }^{\mathrm{TO} 3} \mid$ ques muerte para mj anjma |

[35.I3] E yo quando adolesco ${ }^{104}$ es mj vesti | do xerga quebrante ${ }^{105}$ conel ayuno | mj anjma \& mj coraçon amj se $\mid$ nnor se torna

[35.I4] commo por amjgo | o hermano mjo ando ${ }^{\mathrm{ro6}}$ commo triste | por madre denegrido me aba $\mid$ xo

[35.I5] E en mj coxedad se alegran | \& se apannan apannanse contra mj viles \& non lo sope Ronpieron | \& non çesaron ${ }^{\mathrm{Ioz}}$

[35.I6] con falsos es

[f. ccclxvj ${ }^{\text {bb }}$ ]

carnjdores viçiosos Reganan ${ }^{\mathrm{Io8}}$ contra $\mid$ mj sus dientes

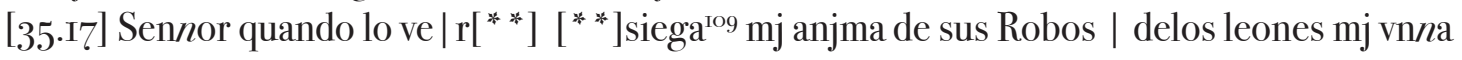
[35.I8] loarte ${ }^{\text {по }}$ enla mu | cha conpanna en pueblo fuerte te ala | bare

[35.rg] non se alegren por mj mjS | enemjgos falsos los que me abo | rresçen ende balde sennalan con El | ojo

[35.20] q que non fablan en paz \& conlos | viçiosos dela tierra Razones \& arte ${ }^{\mathrm{III}} \mid$ Piensan [35.2I] \& alargan contra mj sus | bocas \& dizen plazer \& gozo vido | nuestro ojo [35.22] Vistelo sennor non calles ${ }^{\amalg 2} \mid$ sennor non te aluengues de mj

95. por mj mj] por mj $\mathrm{E}_{3}$.

96. saluaçion] saluaçion so yo $\mathrm{E}_{3_{\mathrm{r}}}$.

97. en balde] en de balde $\mathrm{E}_{3}$.

98. escondier[***]ara] escondieron para $\mathrm{E}_{3}$.

99. b[***] balde $\mathrm{E}_{3}$.

IOo. mala sonada] mal asonada $\mathrm{E}_{3_{\mathrm{I}}}$, donde las dos palabras están escritas juntas.

IOI. el] al $\mathrm{E}_{3}$.

IO2. leuantense] leuantanse $\mathrm{E}_{3}$.

IO3. males por bienes] mala por buena $\mathrm{E}_{3_{1}}$.

IO4. adolesco] adolesçe $\mathrm{E}_{3}$. Error en $\mathrm{E}_{3}$.

Io5. quebrante] \& quebre me $\mathrm{E}_{3}$.

Io6. ando] ande $\mathrm{E}_{3}$.

IO7. çesaron] sseçaron $\mathrm{E}_{3}$.

Io8. Reganan] rregannan $\mathrm{E}_{3}$.

Iog. ve[****] siega] veras sosiega $\mathrm{E}_{3_{\mathrm{I}}}$.

IIO. loarte] loare $\mathrm{E}_{3_{\mathrm{I}}}$. Posible error en $\mathrm{E}_{3_{\mathrm{I}}}$.

III. arte] de artes $\mathrm{E}_{3}$.

II2. calles] calls $\mathrm{E}_{3_{1}}$. Error en $\mathrm{E}_{3_{\mathrm{I}} \text {. }}$. 
[35.23] Re | cuerda ${ }^{\text {I3 }}$ \& espiertate amj juyzio mj | dios \& mj sennor amj pleito.

[35.24] [ $\left.{ }^{*}\right]^{\mathrm{I} 4}$ judgame se $\mid$ nnor ${ }^{\mathrm{II} 5}$ segunt tu justiçia sennor mj dios \& | non se alegren Por mj

[35.25] I non digan | ensu coraçon gozo nuestra anjma njn di | gan tragamos lo

[35.26] auergonçar sean | \& vituperiar sean en vno con los | que se alegran con mj mal vestiran | verguença $\&$ vituperio los que se engran $\mid$ deçen contra mj

[35.27] פ" ${ }^{\amalg 16}$ cantaran \& ale | grarsean los que han voluntad | de mj justiçia \& diran sienpre cresçera | el sennor que ouo voluntad dela paz $\mid$ desu sieruo

[35.28] \& mj lengua fablara tu | justiçia todo el dia tu loor

[36.I] Capitolo | .xxxvjo ${ }^{\circ}{ }^{17}$ el que esfuerça por el sieruo del | sennor Por daujd fijo de ysay ${ }^{\text {In8 }}$

[36.2] E $\mathrm{E}(3) 1$ deytado del pecador por | el malo que es entre | mj vientre non es El | mjedo de ${ }^{\text {II9 }}$ dios ante ${ }^{\mathrm{I20}}$ sus $\mid$ ojos

[36.3] quelo alaba ${ }^{\text {I2I }}$ ael asus ojos | para fablar su pecado por aborresçer |

[36.4] las palabras de su boca es maldad $\mid \&$ arte dexaste de atender ${ }^{122} \&$ de fazer $\mid$ bien

[36.5] I maldad Piensa en su Ca | ma esta en camjno que non es | bueno el mal non aborresçe

[36.6] el | sennor enlos çielos es tu merçet E | tu verdat fasta los çielos

[36.7] la tu lj | mosna es commo los montes fuertes | los tus juyzios commo el abismo |

\subsubsection{Fragmento B}

[f. ccclxxvij $\left.{ }^{\mathrm{ra}}\right]$

[78.25] a fartura

[78.26] fizo mouer solano por | el çielo \& fizo gujar con su fortaleza | a teman

[78.27] \& fizo llouer sobrellos commo | tierra carne \& commo arena dela mar aues | de ala

[78.28] \& echolos ${ }^{123}$ por medio de su hues | te en derredor de sus moradas

[78.29] \& Co $\mid$ mjeron \& fartaronse mucho \& su de $\mid$ seo $\operatorname{los}^{124}$ troxo aellos

[78.30] non se farta| ron $^{125}$ de su deseo 9 avn estaua su Co $\mid$ mer en sus bocas

[78.3I] \& la yra de dios | creçio enellos \& mato ensus ma | yorales \& los escogidos de yrrael | fizo

Rodillar

[78.32] con todo esto pecaron $\mid$ mas \& non creyeron en sus mjla $\mid$ gros

[78.33] \& acabo enla nada sus di | as \& sus annos enel atoruamjento |

[78.34] si los mataua \& Requerianlo \& torna | uan \& Requerian a dios

[78.35] E nenbra | uanse que dios es su criador \& el po | deroso alto su de Redemjdor

[78.36] \& enganna | uan lo con sus bocas \& con sus len $\mid$ guas le mentian ael

[78.37] \& su coraçon | non era aderesçado conel njn creyan | en su pleytesia

II3. Recuerda] rrecuerdate $\mathrm{E}_{3}$. Error en $\mathrm{S}_{2}$.

II4. [*]] פ $\mathrm{E}_{3}$.

II5. sennor] om. E $_{3_{1}}$.

II6. 9] om. $\mathrm{E}_{3}$.

II7. .xxxvj ${ }^{\circ}$.] .xxxvj. $\mathrm{E}_{3_{1}}$.

II8. fijo de ysay $9 \mathrm{om} . \mathrm{E}_{3_{1}}$.

II9. de] a $\mathrm{E}_{3}$.

I2O. ante] ant $\mathrm{E}_{3}$.

I2I. alaba] allana $\mathrm{E}_{3}$.

I22. atender] entender $\mathrm{E}_{3}$. Error en $\mathrm{S}_{2}$.

I23. echolos] echolas $\mathrm{E}_{3}$. Error en $\mathrm{S}_{2}$.

I24. los] les $\mathrm{E}_{3}$. Erroren $\mathrm{S}_{2}$.

I25. fartaron] $\mathrm{E}_{3}$ enfadaron $\mathrm{E}_{3}$. 
[78.38] \& el es piadoso $\mathrm{E}^{\mathrm{12} 6} \mid$ perdona el pecado \& non estruye | \& acresçienta en sosegar su yra | \& non Recuerda toda su sanna

[78.39] E | nenbrose que de carne eran ${ }^{127}$ es $\mid$ prito [sic] que va \& non torna

[78.4O] quanto ${ }^{128}$ Re | bellaron contra el enel desierto | lo fizieron ${ }^{129}$ entristeçer enla secu | ra [78.4I] \& tornaron \& prouaron a dios | \& al santo de yrrael asennalaron |

[78.42] non se nenbraron del su poderio | el dia que los Redimjo del ene $\mid$ mjgo

[78.43] que puso en egipto sus se | nnales \& sus mjlagros enel canpo | de çohan

[78.44] \& trastorno en sangres ${ }^{130} \mid$ sus Rios \& de sus gotas non be $\mid$ ujan

[78.45] soltaua enellos mestura | \& comjalos \& Ranas \& dannaualos |

[78.46] \& dio al lagostino su esquilmo E | su trabajo ala lagosta

[78.47] estruyo | con pedrisco sus vides ${ }^{131} \&$ sus cabra | figos conla elada

[78.48] \& entrego al | pedrisco sus bestias \& sus ganados | alas brasas

[78.49] soltaua enellos el | ençendimjento de su yra sanna |

[f. $2^{\mathrm{rb}}=$ f. ccclxxvij $\left.{ }^{\mathrm{rb}}\right]$

$\&$ postema $\&$ angustia enbia mjento $\mid$ de angeles ${ }^{132}$ malos

[78.50] pasaua ${ }^{\mathrm{I33}}$ camj | no para su yra \& non deuedo dela | muerte sus anjmas \& sus anjmas $\mid$ ala mortandat entrego

[78.5 $]$ [\& mato todo | primogenjto en los egibtanos ${ }^{134} \mathrm{el} \mid$ comjenço delas fuerças delas tien $\mid$ das de ham $^{135}$

[78.52] E E fizo mouer commo | las ouejas su pueblo \& gujolos | commo la manada por el desierto [78.53] \& | gujo los en sosiego \& non temjeron | \& asus enemjgos cubrio la mar

[78.54] \& | troxolos al monte desu santidad | \& ${ }^{136}$ aqueste monte que crio su dies | tra

[78.55] \& desterro delante dellos genti $\mid{ }_{\text { }}$ s $^{137} \&$ echolos $^{13^{8}}$ en suerte \& heredad | \& fizo morar en sus tiendas | los tribos de yrrael

[78.56] \& prouaron \& Re | uellaron contra dios alto \& sus | testimonjos non guardaron

[78.57] $]^{139} \mid$ E tornaron \& falsaron commo sus | padres trastornaronse commo arco | de enganno

[78.58] \& ensannaronlo con sus | alturas \& con sus dolados le fizi | eron auer enbidia

[78.59] oyolo dios | \& ensannose \& aborresçio mucho A | yrrael

[78.60] E dexo el tabernaculo | de silo la tienda enque moro con los | omes

[78.6r] E E dio al catiuerio su for | taleza \& su fermosura en mano | del enemjgo

[78.62] \& entrego al espada $\mid$ su pueblo \& con su heredad se ensa $\mid$ nno

[78.63] sus mançebos quemo fue $\mid$ go \& sus virgines non fueron ala $\mid$ badas

I26. E] om. $\mathrm{E}_{3}$.

127. eran] $\mathrm{eraE}_{3}$. Probable error en $\mathrm{E}_{3_{1}}$.

128. quanto] quando $\mathrm{E}_{3_{1}}$. Error en $\mathrm{E}_{3_{1}}$.

I29. fizieron] fezieron $\mathrm{E}_{3}$.

I30. sangres] sangre $\mathrm{E}_{3}$. Error en $\mathrm{S}_{2}$.

I3I. vides] vidas $\mathrm{E}_{3}$. Error en $\mathrm{E}_{3}$.

132. angeles] angels $\mathrm{E}_{3}$. Error en $\mathrm{E}_{3}$.

I33. pasaua] gesaua $\mathrm{E}_{3}$.

134. egibtanos] agibtanos el $\mathrm{E}_{3}$.

I35. ham $\mathrm{S}_{2} \mathrm{E}_{3}$ I Cam el resto de traducciones, salvo $\mathrm{Arrag}_{2}$ que lleva Cham.

I36. \&] om. $\mathrm{E}_{3_{1}}$.

137. gentios] gentio $\mathrm{E}_{3_{1}}$. Las demás traducciones llevan un sustantivo en plural; $\mathrm{E}_{3_{\mathrm{I}}}$ opta por un colectivo (singular)o

bien comete un error.

I38. echolos] echoles $\mathrm{E}_{3_{1}}$.

I39. I] om. $\mathrm{E}_{3}$. 
[78.64] sus saçerdotes con espada | cayeron \& sus biudas non llora | uan [78.65] despertose commo si dormja | 9 el sennor commo barragan que can $\mid$ ta conel vjno [78.66] \& firio a sus enemj | gos atras vituperio para sienpre | les dio aellos [78.67] \& aborresçio la tien $\mid$ da de josep \& el tribo de esfraym ${ }^{\mathrm{I} 4 \mathrm{O}}$ non $\mid$ escogio [78.68] \& escogio el tribo de juda el | monte de sion que amo [78.69] [ [*] ${ }^{\text {Ti1 }} \&$ adefi $\mid$ co en alturas su santidad en tierra | que la açimento para sienpre [78.70] \& escogio en daujd su serujdor

\section{[f. ccclxxvij ${ }^{\mathrm{va}}$ ]}

E tomolo delos apriscos delas | ouejas

[78.7I] I detras las prennadas lo | traxo para Regir a Jacob su pueblo | e a yrrael su heredat [78.72] \& gujolos con | sanjdat de su coraçon \& con enten | dimjento de sus palmas los gujo | [79.I] capitolo .lxxjx. ssalmo a açaff | S(3)ennor dios entraron | gentios en tu heredat | ensuziaron $\mathrm{en}^{\mathrm{I} 4^{12}}$ tu pa | laçio santo pusieron | a jerusalem por montones

[79.2] dj | eron el cuerpo de tus serujdores | a comer alas aues delos çielos | la carne de tus buenos alas besti $\mid$ as dela tierra

[79.3] vertieron su san $\mid$ gre commo agua derredor de iherusalem $\mid$ \& non auja qujen los soterrase [79.4] I | fuemos vituperio a nuestros vezjnos | escarnjo \& denuesto a ${ }^{\mathrm{I} 43}$ nuestros derredo | res [79.5] fasta quando sennor te ensannaras | para sienpre \& se ençendera commo | fuego tu enbidia [79.6] trastorna tu sanna | sobre los gentios que non te cono | çieron \& sobre Reyes que tu [[nonbre]] non lla | maron

[69.7] פ que comjeron a Jacob \& | asu morada solaron

[79.8] I non Remjen | bres anos los | pecados primeros A | yna se nos se nos adelante tus Piadades | que somos mezquinos mucho

[79.9] A | yudanos dios de nuestra saluaçion por | causa dela onrra del tu nonbre \& | escapanos \& perdona nuestros pecados | por tu nonbre

[79.Io] [*] ${ }^{\text {I44 }}$ porque diran los gen | tios adolo su dios sea sabido en | los gentios a nuestros ojos la vengan | ça dela sangre de tus serujdores | la vertida

[79.II] I entrara delante ti El | gemjdo del Catiuo con la grande | za detu braço suelta los fijos mu| ertos

[79.I2] \& torna a nuestros vezjnos siete | tanto asu seno el vituperio que | te bituperiaron sennor [79.I3] \& nos | somos tu pueblo \& ouejas de | tu pasto loaremos aty para sien | pre ageneraçion \& generaçion | contaremos tu loor

[8o.I] g capitulo | .lxxx. el que esfuerça con lirios testi |

\section{[f. ccclxxvij $\left.{ }^{\text {bb }}\right]$}

monjo A açaff E salmo. I।

[8o.2] E(3)l pastor de yrrael escucha | el que guja commo las o | uejas a Josep el mora | dor delos cherubim a cata |

[80.3] ante efraym ${ }^{\mathrm{I} 55} \&$ bjnnamjn E | manase Recuerda tu barraganja | \& anda saluanos

[80.4] dios tornanos | \& alunbra tu cara \& seremos sal | uos

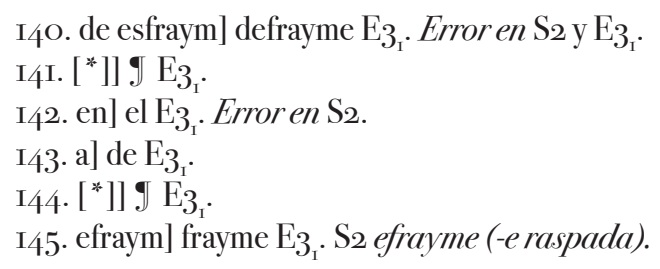


[80.5] el sennor dios sabaod fasta | quando te ensannaras con la oraçion | de tu pueblo [8o.6] fezistelos comer pan | con lagrjma \& disteles a beuer la $\mid \operatorname{grima}^{\mathrm{I} 46}$ con medida [80.7] פ pusistenos | por Roydo a nuestros vezjnos \& nuestros e | nemjgos escarnesçen de nos [8o.8] d dios | sabaod tornanos \& alunbra tu ca $\mid \mathrm{rrera}^{\mathrm{T} 47}$ \& seremos saluos.

[8o.9] [ [ ${ }^{\mathrm{I} 4^{8}}$ la vid que | de egipto feziste mouer desterras | te los gentios \& Plantaste $1 \mathrm{a}^{\mathrm{I} 49}$ [80.Io] $\mathbb{T} \mid$ esconbraste delante dellos aRay $\mid$ gaste sus Rayzes \& fincho la tierra $\mid$ cubrieron $^{150}$ [80.II] $\operatorname{los}^{151}$ montes su sonbra | \& sus Ramos ${ }^{152}$ los alerzes fuertes |

[8o.I2] I tendera sus Ramos ${ }^{153}$ fasta la mar | \& al Rio sus bastagos

[80.I3] por que apor | tellaste su valladar \& cogieron la | todos los que pasan por el camj | no

[8o.I4] I E astragola ${ }^{154}$ el puerco deL | monte \& el anjmanja del canpo | la paçio

[8o.I5] dios sabaod torna ${ }^{155}$ a | gora mjra delos çielos \& vee \& | menbrate desta | vid

[8o.I6] \& la plan | tia que planto tu diestra \& sobre | el Ramo que a Reziaste para ty |

[80.I7] quemada es en fuego \& corta $\mid$ da del denuedo de tu cara se perdi| eron

[8o.I8] sea tu mano sobrel omne | de tu diestra $\&^{156}$ sobrel fijo del omne | que a Reziaste para ty

[8o.I9] \& non | nos tiraremos ${ }^{157}$ de ty danos la vj | da \& tu nonbre llamaremos |

[8o.20] Sennor dios sabaod tornanos | alunbra tu cara \& seremos saluos.

[8I.I] I capitulo .lxxxj. salmo A açaff $5^{8}$ |

[8I.2] C(2)antad adios que es ${ }^{159}$ nuestra | fortaleza tanned a dios [***]

I46. lagrima] lagrimas $\mathrm{E}_{3}$.

I47. ca| rrera] cara $\mathrm{E}_{3}$. Error en $\mathrm{S}_{2}$.

I48. 9 om. $\mathrm{E}_{3}$.

I49. \& Plantaste la] om. $\mathrm{E}_{3_{1}}$.

I5O. E $_{3_{\mathrm{I}}}$ om. 80.IO.

I5I. los] \& $\mathrm{E}_{3}$.

I52. Ramos] rramas $\mathrm{E}_{3}$.

I53. Ramos] rramas $\mathrm{E}_{3}$.

I54. E astragola] estragola $\mathrm{E}_{3_{\mathrm{I}}}$.

I55. torna] rretorna $\mathrm{E}_{3_{\mathrm{I}}}$.

I56. \&] que $\mathrm{E}_{3}$.

I57. tiraremos] tiremos $\mathrm{E}_{3}$.

I58. salmo A açaff] salmo sobre la gujtarra a açaf $\mathrm{E}_{3_{i} \text {. }}$

I59. que es] sobre $\mathrm{E}_{3}$. 


\section{Obras citadas}

Alturo i Perucho, Jesús. I99o. 'Los estudios sobre fragmentos y membra disiecta de códices en Cataluña: breve estado de la cuestión'. Memoria Ecclesiae, ed. by Josep Maria Martí Bonet and Matías Vicario Santamaría (Barcelona: Akribos), I: Los archivos de la Iglesia, presente y futuro, pp. $33^{-} 5^{2}$

Alturo i Perucho, Jesús. 1999. Studia in codicum fragmenta. (Bellaterra: Universitat Autònoma de Barcelona)

Andrés Fernández, David; Martí Martínez, Cristina. 2OI7. 'Fragmentos de códices litúrgicomusicales en España: apuntes para una historiografía y una propuesta de descripción', Hispania Sacra 69.I39: 49-6o. <https://doi.org/Io.3989/hs.20I7.004> [accessed 29/o4/20I8]

Avenoza, Gemma. 2OII. Biblias castellanas medievales (Logroño: CILENGUA; Fundación San Millán de la Cogolla)

Avenoza, Gemma. 20I7. 'Fragmento de Biblia romanceada reutilizada como cubierta de un legajo procedente del Monasterio de Santa María de la Sisla', Sefarad, 77.2: 289-313< $<\underline{\text { htps: } / / \text { doi. }}$ org/IO.3989/sefarad.oI7.OIO>

Avenoza, Gemma. En prensa a. 'Nuevo testimonio de la Biblia en romance (Salmos 32.II-36:7 y 78:25-8I:2): un bifolio reutilizado como encuadernación', in Avatares y perspectivas del medievalismo ibérico, ed. by Isabella Tomassetti et al. (San Millán de la Cogolla: Cilengua)

Avenoza, Gemma. En prensa b. 'The Old Testament in Translated Patristic Works: Ezek I-4.3 and 4O.I-47 in Fr. Gonzalo de Ocaña's (I442) Spanish Translation of Homiliarum in Ezechielem Prophetam libri duo by Pope Gregory I', in Translating Sacred Texts, ed. by Fernando Rodríguez Mediano, Mercedes García-Arenal and Camilla Adang (Leiden: Brill)

Barco, Javier del; Panizo Santos, Ignacio. 20Io. 'Fragmentos de incunables hebreos en documentos inquisitoriales del Tribunal de Calahorra-Logroño', Huarte de San Juan: Geografía e Historia I7: 295-308

Biblia 1975: Cantera Burgos, Francisco; Iglesias González, Manuel (ed.). 1975. Sagrada Biblia: versión crítica sobre los textos hebreo, arameo y griego, 2 vols, Biblioteca de Autores Cristianos Series Maior, 25-26 (Madrid: Editorial Católica)

Bibliamedieval.es: Enrique-Arias, Andrés; Pueyo Mena, F. Javier, Proyecto Biblia Medieval $<$ http:// bibliamedieval.es $>$ [accessed 20-O3-20I8]

BITECA: Bibliografia de Textos Catalans, Valencians i Balears Antics, ed by Gemma Avenoza, Lourdes Soriano and Vicenç Beltran $<$ https://tinyurl.com/mzuqlzj $>$ [accessed 2O-O3-2OI8]

Bobichon, Philippe. 2009. Le Lexicon: Mise en page et mise en texte des manuscrits hébreux, grecs, latins, romans et arabes (Paris: École Thématique) $<$ https://cel.archives-ouvertes.fr/celo037767I/document>

Caballero García, Antonio. 2005. 'Desamortización y patrimonio documental: un ejemplo de tratamiento de archivos en el s. XIX', Signo, I5: 77-II $<$ https://ebuah.uah.es/dspace/ handle/IOOI $7 / 762 \mathrm{I}>$

Casanellas, Pere. 20I4. 'Medieval Catalan Translations of the Bible', in Les veus del sagrat, ed. by Xavier Terrado and Flocel Sabaté (Lleida: Pagès Editors), pp. I6-34 
Casanellas, Pere. 20I5. 'Versiones bíblicas catalanas e Inquisición: fragmentos de biblias catalanas encontrados entre la documentación inquisitorial conservada en el Archivo Histórico Nacional de Madrid', in III Simpósio Internacional de Estudos Inquisitoriais: novas fronteiras (Alcalá de Henares, 2015) (Cachoeira: Anais Eletrônicos), pp. I-20 <https://tinyurl.com/yzmmzako $>$ [accessed 2I/IO/2OI7]

CDH: Corpus del Nuevo diccionario histórico (CDH) (Madrid: Instituto de Investigación Rafael Lapesa de la Real Academia Española) < $\underline{\text { http://web.frl.es/CNDHE }>\text { [accessed II/O4/2OI8] }}$

Cruz Herranz, Luis Miguel de la. 2003. 'La Sección de Clero del Archivo Histórico Nacional', in II Jornadas Científicas sobre Documentación de la Corona de Castilla (siglos XIII-XV), ed. by Juan Carlos Galende Díaz (Madrid: UCM), 375-434<https://tinyurl.com/yolfl-7d6>

Enrique-Arias, Andrés; Pueyo Mena, F. Javier. 20I7. 'La Biblia completa del Marqués de Santillana', Revista de Filología Española, 97.I: 35-68 <https://doi.org/IO.3989/rfe.2OI7.02>

Fradejas Rueda, José Manuel. 20I5a. 'Pequeños tesoros vallisoletanos' in his Crítica textual para dummies, 3O-OI-2OI5 $<$ https://ecdotica.hypotheses.org/I226 $>$ [accessed 2O-O3-2OI8]

Fradejas Rueda, José Manuel. 20I5b. 'Cuatro nuevos testimonios manuscritos de las Siete Partidas', Revista de Literatura Medieval, 27: 13-52 <http://dx.doi.org/IO.I76I3/M62 $\mathrm{H}_{32}>$

García Larragueta, Santos A. 1987. 'El apeo, documento diplomático’, Anuario de Estudios Medievales, I7: 6I7-36

Hidalgo-Pardos, Juan Antonio. 20I6. 'Noticia de un nuevo archivo histórico privado: índice de documentación medieval del Monasterio Jerónimo de Santa María de la Sisla (Toledo) del Archivo Antonio Hidalgo Sánchez (I3OI-I498)', Cuadernos Medievales, 2I: 49-92 < $\underline{\text { https://tinyurl.com/ }}$ ydxw8kyh>

Lazar, Moshe (ed.). r996. Biblia de Ferrara (Madrid: Fundación José Antonio de Castro)

Iglesias-Fonseca, J. Antoni. 200o. 'Un bifoli en pergamí de la parròquia barcelonina de Vilanova del Vallès: el testimoni en català més antic del Llibre de conservació de sanitat de Joan de Toledo (s. XIV)', Arxiu de Textos Catalans Antics, I9: 389-426

Iglesias-Fonseca, J. Antoni. 20Io. 'Uno de los testimonios conocidos más antiguo de un Bestiari en catalán (Arxiu Històric de Girona, colección de fragmentos), in Actas del XIII Congreso Inernacional de la AHLM (Valladolid, 20og), ed. by José Manuel Fradejas et al. (Valladolid: Universidad; Ayuntamiento), II: IO47-54

Iglesias-Fonseca, J. Antoni. 20I3. 'Comunicar también es conservar', in Communicatio: un itinerari històric, ed. by J. Antoni Iglesias-Fonseca (Murcia: Nausícaä), pp. 65-I3I

Iglesias-Fonseca, J. Antoni; Perujo Melgar, Joan M. 20I4. 'La visió del cavaller Louis d’Auxerre: edició crítica de la versió catalana', Revista de Literatura Medieval, 26 : $13-73<\underline{<t t p: / / h d l . h a n d l e . ~}$ net/IOOI7/23784>

López Villalba, José Miguel. 2002. 'Los estudios diplomáticos sobre documentación municipal española: ¿Una ilusión pasajera?’, in Littera scripta in honorem Prof. Lope Pascual Matínez, ed. by Francisco Marsilla de Pascual (Murcia: Universidad de Murcia), II: 575-96

Madoz, Pascual. I806-I87o. Diccionario geográfico-estadístico-histórico de España y sus posesiones de ultramar, i6 vols (Madrid: Est. Literario-Topográfico de P. Madoz y L. Sagasti)

Millares Carlo, Agustín. 1983. Tratado de paleografía española, 3 vols (Madrid: Espasa Calpe) 
Nogal Fernández, Rocío de la; Barco, Javier del. 2013. 'Judaizantes y textos hebreos en el Tribunal de la Inquisición de Navarra: el proceso de fe contra Martín López (I52O-I52I)', Huarte de San Juan: Geografía e Historia, 20: 7I-86

Philobiblon/BETA: Bibliografía Española de Textos Antiguos, ed. by Charles Faulhaber, Ángel Gómez Moreno and Óscar Perea Rodríguez (Berkeley: Bancroft Library 1997-), <https:/ /tinyurl.

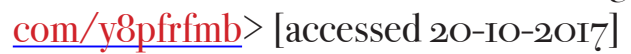

Pueyo Mena, Francisco Javier. 2008. 'Biblias romanceadas y en ladino', in Sefardíes: literatura y lengua de una nación dispersa, ed. by Iacob M. Hassán, Ricardo Izquierdo Benito and Elena Romero (Cuenca: Universidad de Castilla-La Mancha), pp. 193-263

Pueyo Mena, Francisco Javier. En preparación. 'Observaciones complementarias al sistema traductológico de $\mathrm{E}_{3}{ }_{\text {' }}$

Pueyo Mena, Francisco Javier; Enrique-Arias, Andrés. 20I3. 'Los romanceamientos castellanos de la Biblia Hebrea compuestos en la Edad Media: manuscritos y traducciones', Sefarad, 73.I: I65224 〈https://doi.org/IO.3989/sefarad.oI3.006>

Riera i Sans, Jaume. 20I3. 'Bíblies en català no cremades per la Inquisició', Butlletí de l’Associació Bíblica de Catalunya, II5: 4I-70 $<\underline{\text { https://tinyurl.com/y7l } 35 \mathrm{kpa}}>$

Rodríguez Molina, Javier. 20ı6. 'Un romanceamiento bíblico neotestamentario desconocido y la primera versión castellana de la Catena aurea’, Revista de Filología Española, 96.2: 289-323 < $\underline{\text { https://doi.org/IO.3989/rfe.2OI6.IO }}>$

Ruiz Asencio, José Manuel. 1998. 'La colección de fragmentos latinos de la Chancillería de Valladolid', in Actas del II Congreso Hispánico de Latín Medieval, ed. by Maurilio Pérez González (León: Universidad de León), I: I75-85

Sanchez de Villajos, Mateo. I752. Reglas y estadal de medir tierras para aviso de los agrimensores (Madrid: Juan de Zúñiga)

Sanz Fuentes, María Josefa. 20I5. 'De diplomática concejil: estado de la cuestión', in Lugares de escritura: la ciudad, ed. by Pilar Pueyo Colomina (Zaragoza: Institución Fernando el Católico; Diputación de Zaragoza), pp. I6-29 